Bartın University Journal of Faculty of Education, 8(1), 322-359

Bartın Üniversitesi Eğitim Fakültesi Dergisi, 8(1), 322-359

buefad.bartin.edu.tr

\title{
Descriptive Analysis of the Articles Published in the Last 10 Years within the Context of Lifelong Learning
}

\author{
Ahmet Emre KILIÇ*a, Ramazan YILMAZ ${ }^{\mathrm{b}}$
}

\begin{tabular}{l} 
Article Info \\
\hline DOI: 10.14686/buefad.490131 \\
\hline Article History: \\
Received 01.07.2018 \\
Accepted 28.01.2019 \\
Published $\quad 01.02 .2019$ \\
\hline Keywords: \\
Lifelong learning, \\
Trends in research, \\
Article review, \\
Descriptive analysis. \\
\hline Article Type: \\
Research Article \\
\end{tabular}

\begin{abstract}
The purpose of this study is to analyze in a descriptive way the published work within the context of lifelong learning in the last decade. For this purpose, the SCIExpanded, SSCI and A\&HCI citation indexes in the Web of Science were used. The following search terms were used as appropriate: "Lifelong Learning" and "Lifelong Learning". A total of 297 articles were found in the search results and these studies were analyzed according to the journal they published, the language, the research methods and their participants. This research was prepared using the document review technique within the scope of the survey research model. The data were collected by a form developed by the researchers. The collected data are analyzed descriptively and the results were shown graphically. According to findings, it can be said that the articles were published in 205 different journals, the English language was used the most, the most qualitative methods were preferred as the research method and the participants concentrated on very different samples. It is expected that this research will be a guide for future researches, since such researches on the field of lifelong learning are rarely seen in the literature.
\end{abstract}

\section{Hayat Boyu Öğrenme Kapsamında Son 10 Yıl İçerisinde Yayınlanan Makalelerin Betimsel Analizi}

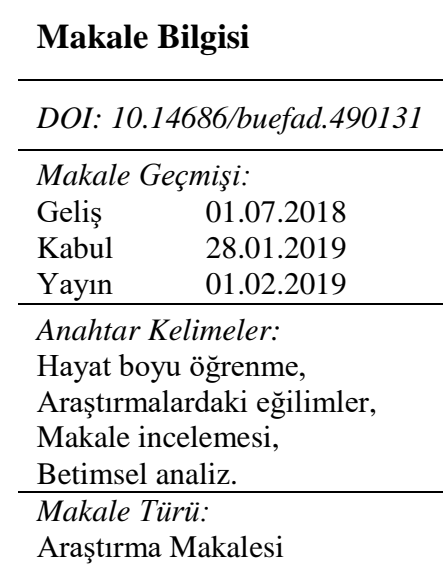

*Corresponding Author: ahmetemre13@gmail.com

a Bartin University, Bartin/Turkey, http://orcid.org/0000-0002-8612-0892

${ }^{\mathrm{b}}$ Assoc. Prof., Bartin University, Bartin/Turkey, http://orcid.org/0000-0002-2041-1750

\begin{abstract}
Öz
Bu çalışmanın amacı, alanyazında son on yıl içinde hayat boyu öğrenme konusunda yayınlanmış çalışmaların betimsel olarak analizini yapmaktır. Bu amaçla Web of Science'da yer alan ve SCI- Expanded, SSCI ile A\&HCI atıf indekslerinde taranan makalelerden yararlanılmıştır. Amaca uygun olarak tarama sürecinde "Lifelong Learning", "Life-long Learning" anahtar kelimeleri kullanılmıştır. Yapılan tarama sonuçlarında toplam 297 makalenin tam metnine ulaşılmış ve bu çalışmalar yayınlandıkları dergilere, yazıldıkları dillere, kullandıkları araştırma yöntemine ve katılımcılarına göre çözümlenmiştir. $\mathrm{Bu}$ araştırma tarama modeli kapsamında doküman incelemesi tekniği kullanılarak yürütülmüştür. Veriler araştırmacılar tarafından geliştirilen bir form ile toplanmıştır. Toplanan veriler betimsel olarak analiz edilmiş olup grafiksel olarak gösterilmiştir. Araştırma bulgularına göre makalelerin 205 farklı dergide yayınlandığı, makaleler yazılırken en çok İngilizce dilinin kullanıldığı, araştırma yöntemi olarak en çok nitel yöntemlerin tercih edildiği ve katılımcıların çok farklı örneklemler üzerinde yoğunlaştığı söylenebilir. Hayat boyu öğrenme alanı ile ilgili bu tür inceleme araştırmalarının alanyazında pek rastlanmamasından dolayı bu araștırmanın gelecek araștırmalar adına yol gösterici olması beklenmektedir.
\end{abstract}




\section{Introduction}

When looked at the history of the world, it is always possible to see an unceasing change and improvement. Living beings at all times and in every term adapt to changes taking place. And we human beings both change our environment and change ourselves. Especially in the very latest century, the things that have been underwent contributed to the increasing of the knowledge that exists on the world by long odds. Increasing of the knowledge and its always being in change urges us, human beings, to be up to date and tend to continual learning. Because of this fast changings and improvements, individuals always feel the needs of learning. To maintain their positions in professional life and to meet the requirements of the era in daily life and even to talk with their own children language of the era, they are obliged to improve themselves. The concept of lifelong learning come to surface at this point in order to meet these needs. Lifelong learning emphasizes the ability to update people from their births to deaths according to the needs of the time they live in, their knowledge, skills or attitudes from their lives, from their surroundings or from anywhere (Ayçiçek, 2016). Hanemann (2015) states that lifelong learning is becoming a necessity, not only in formal education, but especially in those who are disadvantaged or formally not educated.

In the European Commission's (2000), it is defined as all-purpose learning activities undertaken unceasingly in order to improve knowledge, skills and mastery. In the report the importance of lifelong learning is emphasized in order to encourage the transformation of individuals into active citizens and to increase employability. As a result of the current economic and social change in Europe, it is emphasized that a fundamentally new approach to education should be introduced and that all kinds of teaching and learning should be brought together. As a result of globalization, in the new order formed by the disappearance of borders, countries have undergone a process of restructuring, and as a result of this rapid change and development reflected in all fields, the existing mentality of classical education has been shifting towards developing approaches to developing technologies and educational programs compatible with new generation individuals. For this reason, even the most developed countries continually improve their education systems and improve the quality of education. Almost every country is making changes in their education policies and trying to adapt their education systems to this new information system so that today's individuals can gain lifelong learning habits. In other words, countries now need to structure their education systems together with "lifelong learning" policies.

When we take lifelong learning practices of the past into consideration, firstly distance education studies come to mind. Distance education is a teaching method where the limitations of traditional learning - teaching environments are eliminated and communication and interaction between teachers and learners are provided through a variety of specially prepared environments (Alkan, 1987). With the distance education systems, almost everyone can receive education regardless of age and level (Gelişli, 2015). The system, which started with a letter in the USA in the 1700s and continued with the sending of written course materials by post, is the first implementation that can be considered as a distance education (Ergüney, 2015). Implementations which printed materials are sent to people by post / mail can be accepted as the oldest form of distance education (Gelişli, 2015). As approached to our day, radio and television broadcasting applications have started to offer alternative opportunities for distance education systems due to the digitalization of visual and audio content together with new media (Atik \& Ata, 2018). With the computer and internet technologies' opening new gates to education horizon, distance learning platforms have started to attract more attention of individuals. Digital platforms offer both simultaneous and asynchronous training with a self-learning structure. This allows individuals to plan their own training. In recent years, mobile technologies have become widely used as distance education applications. These devices are more easily accessible and cheaper than computers (Karaoğlan Yılmaz, Dilen, \& Durmuş, 2018; Oran \& Karadeniz, 2007). Mobile learning applications can vary to the needs of the people. Mobile performance support systems that improve occupational and user performance, mobile assisted applications as warning and notification, tests and exercises designed for users to evaluate themselves, games and simulations for both entertainment and learning, counselling and guidance services that support interaction and cooperation applications are carried out via mobile devices (Özdamar Keskin, 2010). Together with developing technologies, lifelong learning practices are also changing and developing. These new generation systems, which can be continuously developed and capable of meeting the educational needs of future generations, play an important role in individuals becoming lifelong learners.

The process of acquiring lifelong learning skills should be gained at an early age. Lifelong learning; it includes all kinds of learning that people try to fulfil throughout their lives with the aim of developing knowledge, skills and individual's potential with an individual, social or employment related perspective. Lifelong learning aims to 
involve all individuals who can actively participate in all areas of life, regardless of age, religion, gender, race, or social, economic status (Aksoy, 2008). Therefore, it is very important to place lifelong learning activities in all levels of education and to give these learnings to individuals at an early age. It is necessary to re-emphasize the importance of the concept of lifelong learning for societies. Because, especially in the last few decades, study has been done about the concept of lifelong learning in many countries and new structuring studies are carried out to integrate with this concept. In today's world, where the boundaries have disappeared and the economic order prevails, all societies should better understand the concept of lifelong learning and adapt to their existing systems, and even update their systems if necessary, in order to maintain competitiveness among existing countries.

The changing structure of societies and the development of lifelong learning practices along with the developing technologies make the studies related to the field more valuable. The study to be carried out will reveal the necessary arrangements or needs to develop these practices and to meet the needs of the individuals to the desired extent. The amount of information produced in the new world order, which is in a constant change, increases more and more so the needs of individuals are changing almost every day. On the one hand, technologies make it easier for individuals to reach information, while on the other hand they force individuals to learn and improve themselves. With this change, the continuous updating of the existing branches of profession and new professional groups lead people to keep themselves up to date and to develop their individual skills. With this change, the continuous updating of the existing branches of profession and new professional groups lead people to keep themselves up to date and to develop their individual skills. In this existing order, lifelong learning is important for individuals (Binay Eyüboğlu \& Karaoğlan Yılmaz, 2018). Although studies on the field of lifelong learning have grown even more in recent years, there is hardly any study that analyses and compiles articles in the field. The most effective method in determining the tendencies of the studies in this area and the direction in which these studies are conducted is to analyze the studies carried out in this area (Yenen et al., 2016). When such studies are carried out systematically in certain criteria and within a certain period of time, they are of great importance for drawing a general framework on the subject of study and for having an idea about the studiers who will work in the field (B1kmaz, Aksoy, Tatar, \& Altınyüzük, 2013). From this point, it is aimed to analyze the articles published in the Web of Science from January 2007 to December 2017 on Lifelong Learning subject. Together with this study, it is expected that compiling studies related to lifelong learning will create an important knowledge and fill the gap in the field. Based on the general purpose of the study, the following questions were sought:

1) How is the distribution of the articles to the journals they are published in?

2) How is the distribution of the articles according to the languages they are written?

3) How is the distribution of methods used in articles?

4) How is the distribution of data analysis methods specified in articles?

5) How is the distribution of data collection tools used in articles?

6) What are the rates of participants in the articles?

7) How is the distribution of participants by age?

8) How is the distribution of the sample sizes specified in the articles?

9) How is the distribution of the keywords in the articles?

\section{Method}

\section{Research Model}

This study was prepared using the survey model. The survey model is a researches that are intended to describe the features of a wide range of topics. This kind of researches allows you to answer questions such as "what, where, when, how often, what level, how". The purpose of this type of researches is to take a picture of the current situation of the study subject to describe it (Büyüköztürk, Çakmak, Akgün, Karadeniz, \& Demirel, 2016). The aim of this study is to analyze the articles published in the SCI-Expanded, SSCI and A\&HCI citation indexes that are in the Web of Science between January 2007 and December 2017 in the field of lifelong learning. The following search terms were used as appropriate: "Lifelong Learning" and "Life-long Learning". A total of 297 articles were found 
in the search results and these studies were analyzed according to the journal they published, the language, the research methods and their participants. This research was prepared using the document review technique within the scope of the survey research model. The data were collected by a form developed by the researchers. The collected data are analyzed descriptively and the results were shown graphically.

\section{Data Collection and Analysis}

This study has been carried out by document analysis technique within the framework of the survey model. In the search results of the SCI-Expanded, SSCI and A\&HCI citation indexes published in the Web of Science database between January 2007 and December 2017, 297 articles were analyzed. In the scope of the study, the article review form developed by researchers was used and the data obtained from the articles reviewed were analyzed by using descriptive methods. Findings are presented graphically by giving percentage and frequency information.

\section{Findings}

In this section, the findings and comments obtained for the purpose of the study are given.

\section{Distribution of Articles to the Journals They are Published in}

In line with the purpose of the study, 297 articles obtained after the "Lifelong Learning" search carried out in the Web of Science were published in 205 different journals. "The distribution of these 205 journals to the number of articles that they are published in" is shown in Figure 1.

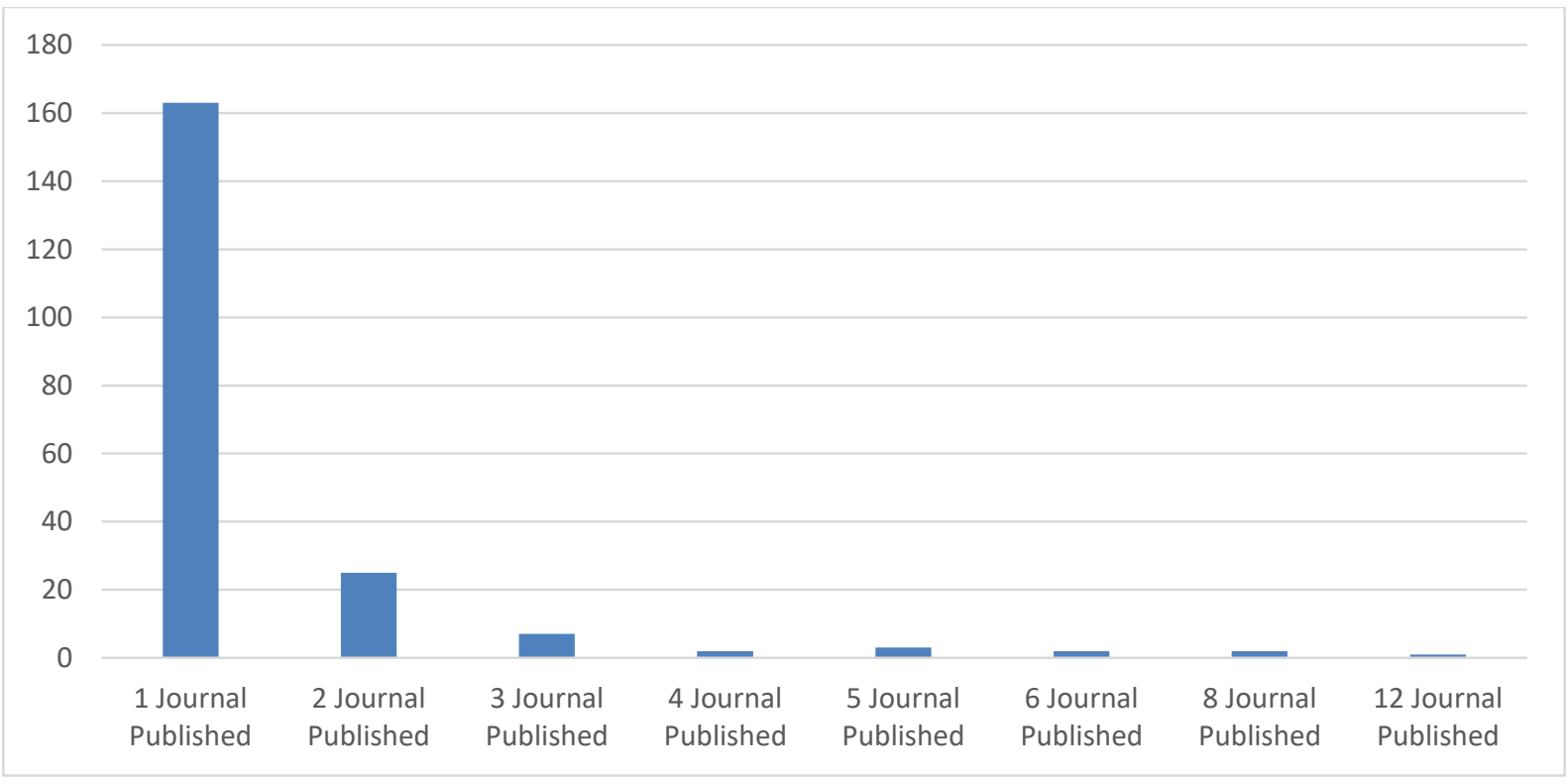

Figure 1. The distribution of these 205 journals to the number of articles that they are published in.

When the journals have been analyzed at, it is seen, articles was published by $169(79.51 \%)$ journals 1 times, $25(12.20 \%)$ journals published 2 times, 7 (3.41\%) journals published 3 times, $2(0.98 \%)$ journals published 4 times, $3(1.46 \%)$ journals published 5 times, 2 (each (0.98\%)) journals published 6 and $2(0.98 \%)$ journals published 8 times, $1(0.49 \%)$ journal published 12 times. According to these data, for the purpose of the study, only 
1 journal on the "lifelong learning" field between January 2007 and December 2017 has published more than 10 publications.

The graphical distribution of 10 journals that published most article is shown in Figure 2. When the data in Figure 2 is analyzed, it is seen that with the number 12 (4.04\%) articles in 297 articles, "European Journal of Education" published the most of articles that were published on journals. This is followed by respectively "Asia Pacific Education Review" and "KEDI Journal of Educational Policy" with the number 8 (2.69\%). with the numbers 6 for each (2.02\%) "Adult Education Quarterly", and "Studies in Continuing Education" journals, with the number $5(1.68 \%)$ "Australian Journal of Adult learning", "Educational Gerontology" and the "International Journal of Engineering Education" with the number 4 (1.35\%) "Journal of Education Policy" and "Academic Medicine". According to these findings, it can be said that the number of journals related to the field of education is higher than the other fields in the top 10 publications.

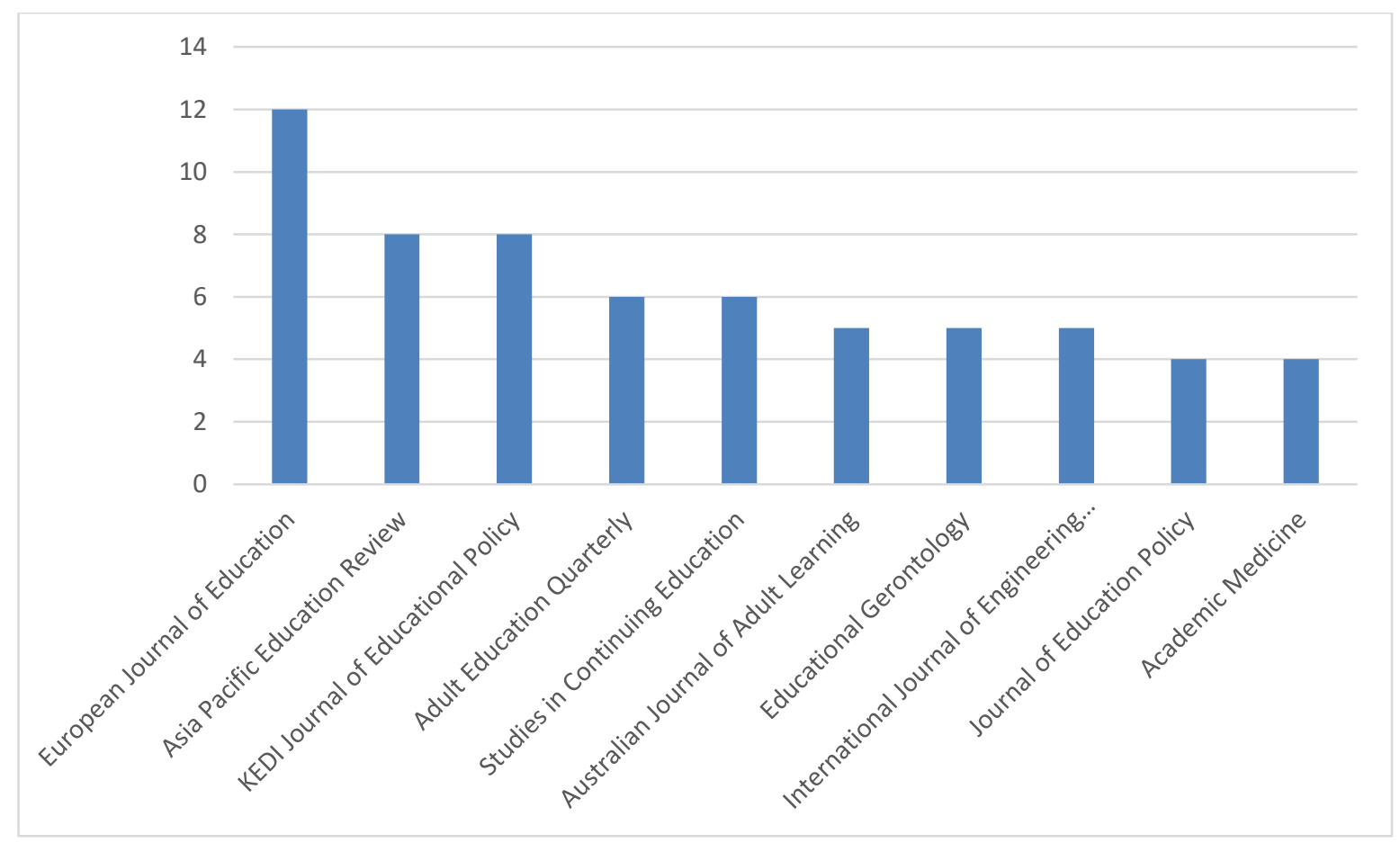

Figure 2. The graphical distribution of 10 journals that published most article

As a result of the studies, after the searches that are carried out, it is seen the number of journals published in those articles in Turkey are 5 (2.43\%) out of 205 journals. Those journals are with the number $3(1.01 \%)$ for each one "Education and Science" and "Hacettepe University Journal of Education", with the number 1 for each one "Public Administration Journal/Amme Idaresi Dergisi", "Bilig" and "TOJET: The Turkish Online Journal of Educational Technology". Graphic distribution of journals that published articles in Turkey shown in Figure 3. 


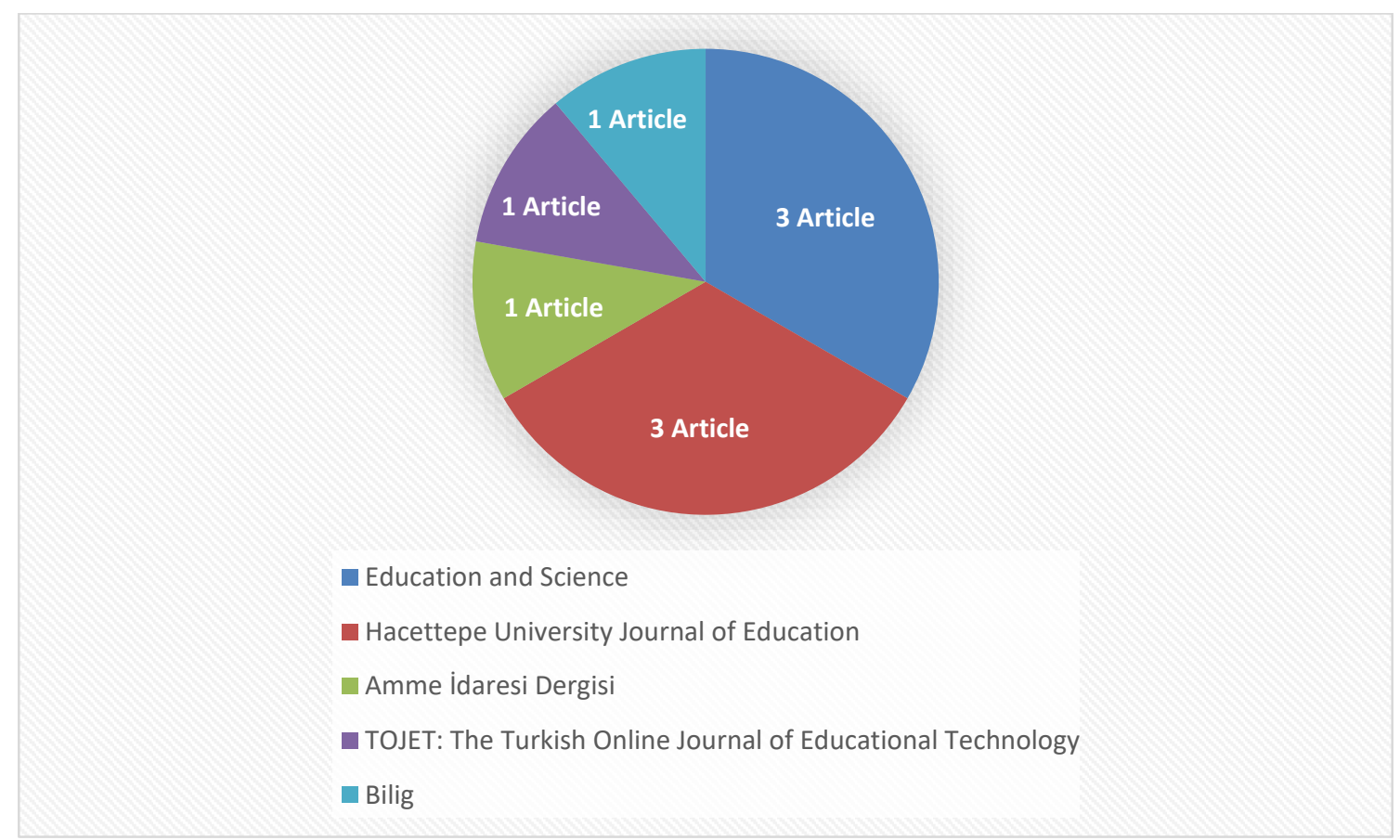

Figure 3. Distribution of journals that published articles in Turkey

\section{Distribution of Articles according to the Language They are Written in}

When the articles are analyzed according to the language they are written in, it is seen English is dominant than the other languages. The distribution of the articles according to the languages they are written in is given in Figure 4. 


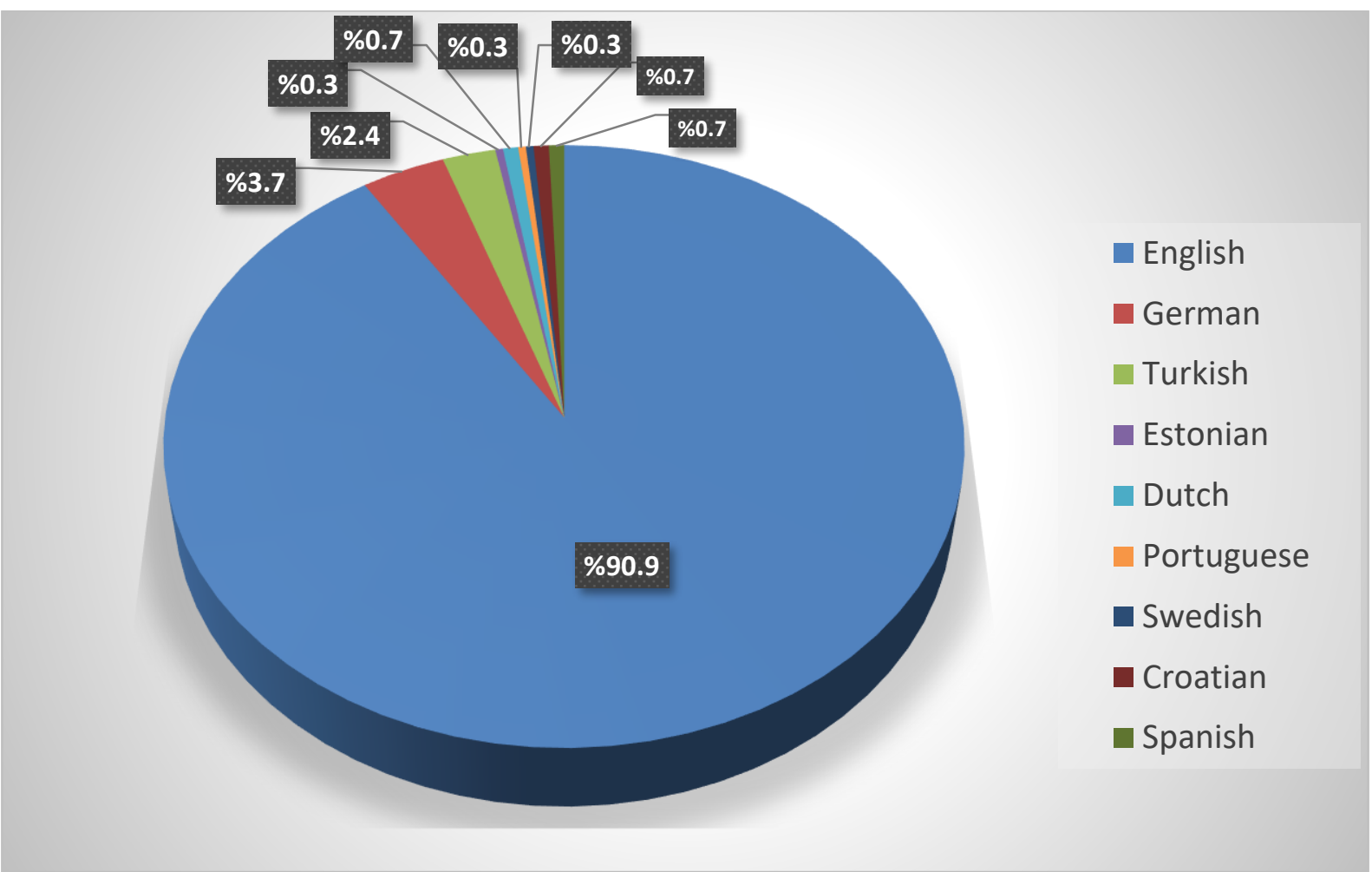

Figure 4. The distribution of the articles to the languages they are written in

When the "distribution of the articles to their languages they are written in" is analyzed, the number of articles written in English is 270 (90.9\%), the number of articles written in German is 11 (3.7\%), the number of articles written in Turkish is 7 (2.4\%), in Dutch, Croatian and Spanish are $2(0.7 \%)$ and 1 was written in Swedish. According to this, the articles in the search results of the Web of Science is seen they are written in English. At this point, it can be said that the English language is the common language used all over the world. The number of articles written in the Turkish language after the English and German languages can be interpreted as a sign of interest in this field in our country.

\section{Distribution of Methods Used in the Articles}

According to the methods used in the search results of the study, the qualitative methods $(\mathrm{n}=185,62.3 \%)$ are preferred in more than half of all studies. Qualitative study was followed by quantitative $(\mathrm{n}=88,29.6 \%)$ and mixed methods $(n=24,8.1 \%)$. The distribution of the articles according to the methods that are used is given in Figure 5. 


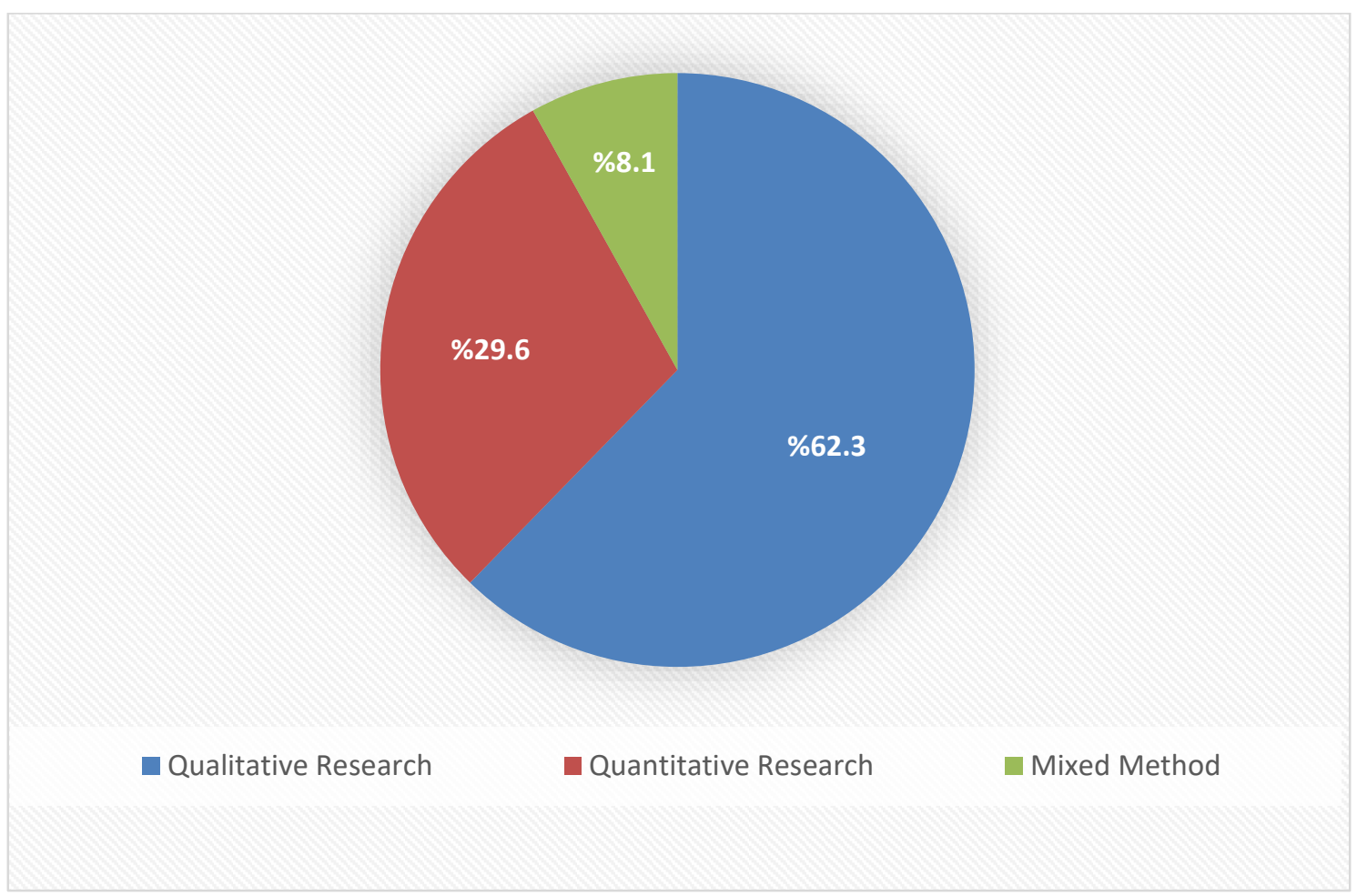

Figure 5. The distribution of the articles according to the methods that are used

When the articles, published in journals that are published in Turkey, are analyzed to the methods they used out of 9 article $4(44.4 \%)$ are qualitative methods, 4 (44.4\%) quantitative methods, and 1 of them (11.1\%) are found to use mixed methods. To the method used by articles published in journals that are in Turkey are given in the graph of Figure 6 shows the distribution.

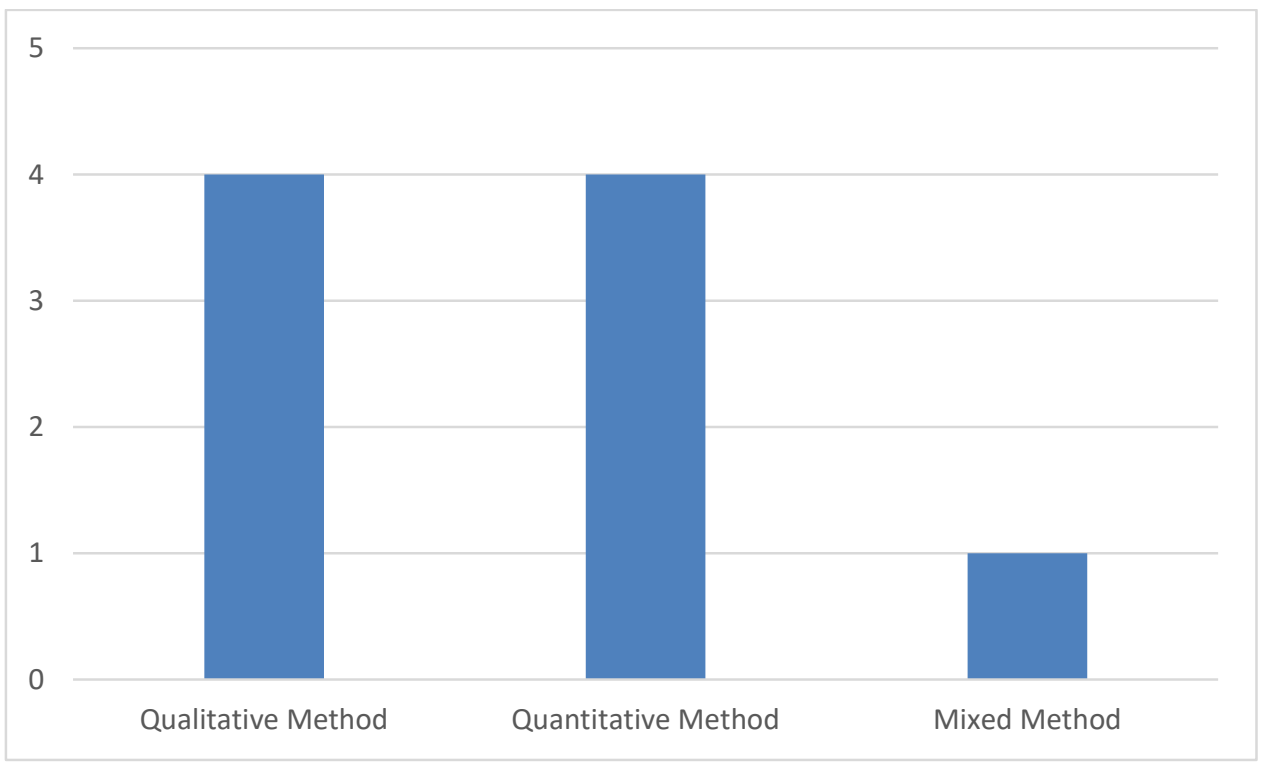

Figure 6. The distribution of the method used by articles published in journals that are in Turkey 


\section{Distribution of Data Analysis Methods Specified in the Articles}

When the data analyze methods articles that are analyzed in the scope of study are examined, while in 198 studies (66.66\%) qualitative data analyze methods is encountered, in 152 studies (51.17\%) quantitative data analyze methods are encountered. Only qualitative data analyze method is used in 135 studies (45.45\%) and only quantitative data analyze is used in 89 studies (29.97\%). Both data analyse methods are used in 63 articles (21.21). In the scope of the research, any data analyze methods isn't specified in 10 articles (3.37\%). Distribution of data analyze methods that are specified in articles is shown in graphic of Figure 7.

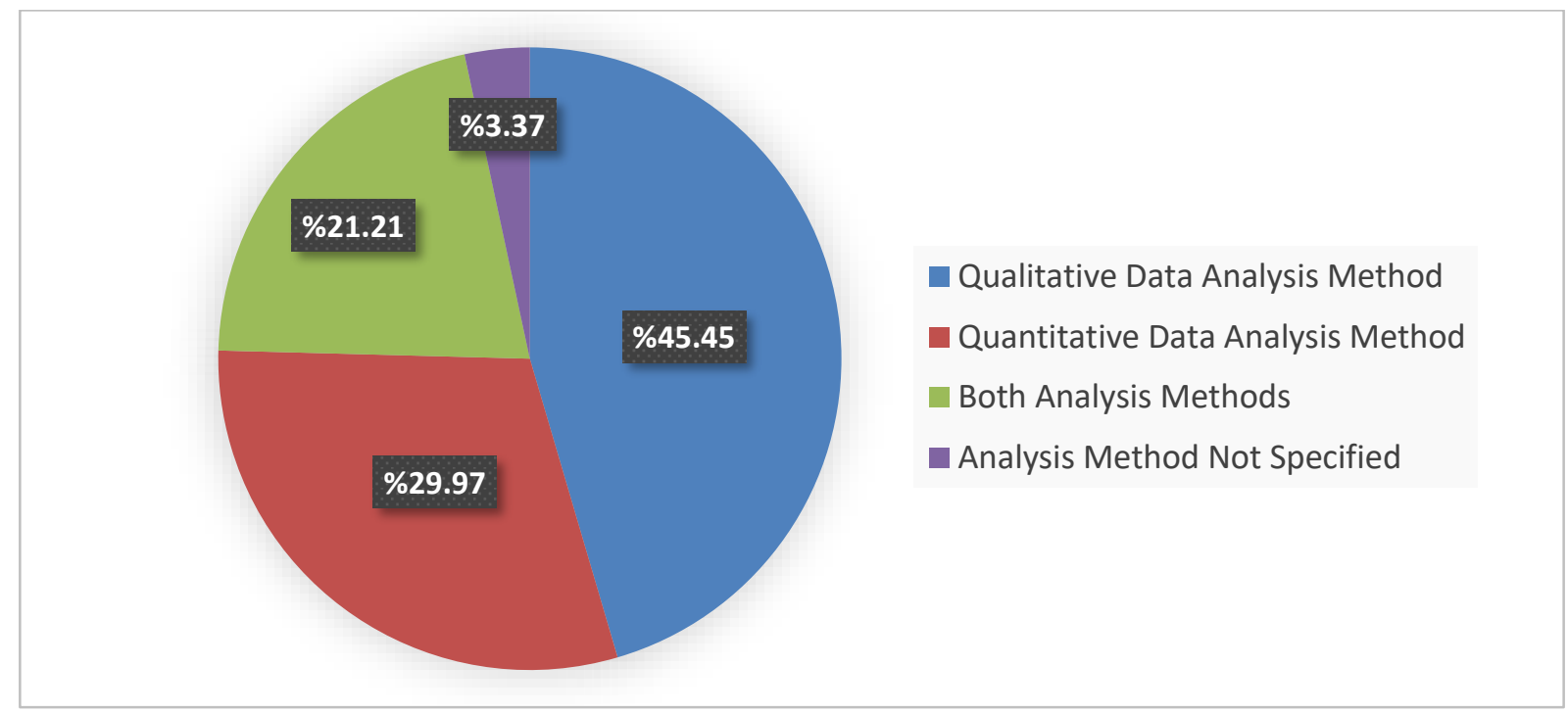

Figure 7. Distribution of data analyze methods that are specified in articles

When the 198 articles are analyzed (66.66\%), it has been seen descriptive analyze methods are preferred more than other qualitative data analyze methods $(\mathrm{n}=102,51.52 \%)$. Content analyse method is used in 83 studies (41.92\%). In 13 articles (6.56) other qualitative data analyze methods are used. Distribution of other data analyze methods in articles is shown in graphic of Figure 8.

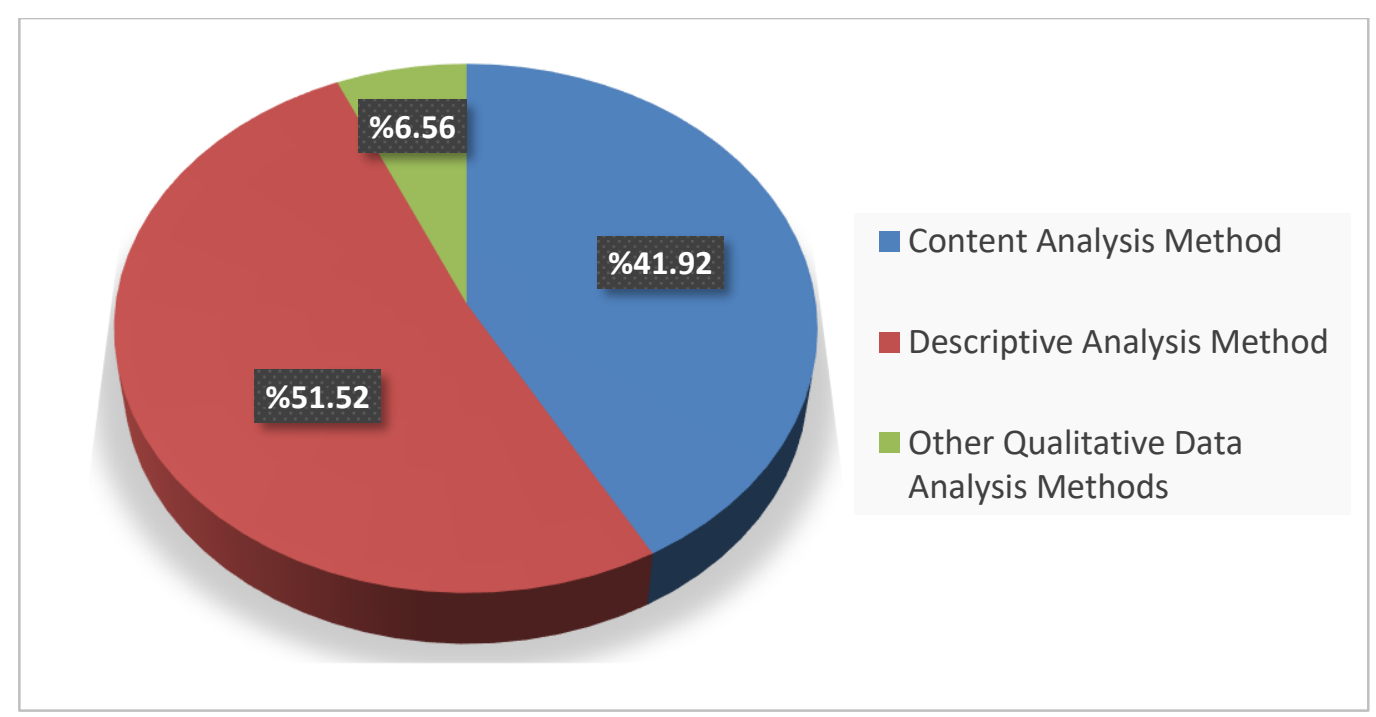

Figure 8. Distribution of other data analyze methods in articles 
In the articles that are analyzed in the scope of this study, in 152 studies that used quantitative data analysis, it has been seen only the descriptive statistics is more than the studies that only used predictive statistics $(n=67$; 44.08\%). In 36 articles (44.08\%). While in 36 articles (23.68\%) used only predictive statistics, it has been seen in 49 articles both type of statistics are used. Distribution of quantitative data analysis in itself is shown in graph of Figure 9.

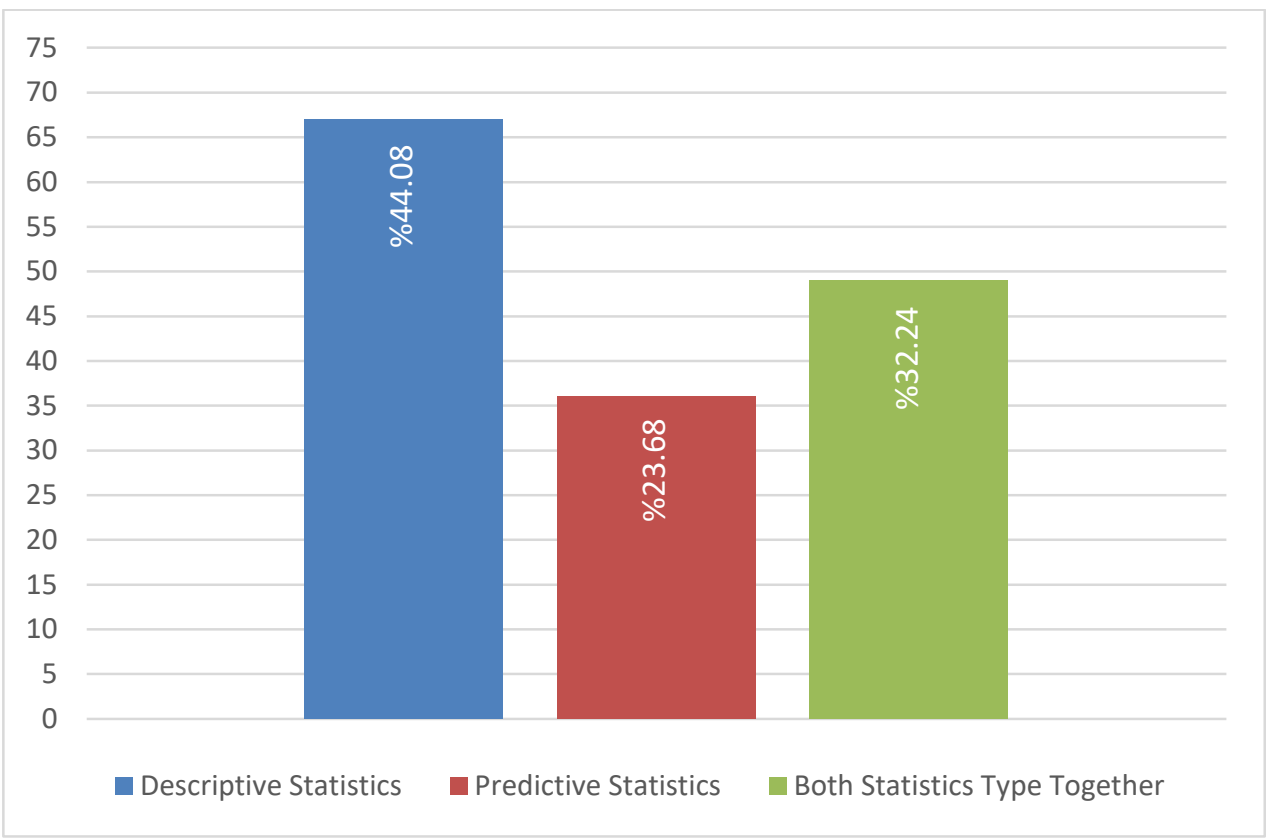

Figure 9. Distribution of quantitative data analysis in itself

In 112 articles (73.68\%) of 152 articles that are used quantities data analyse method used descriptive statistics. When these studies are analyzed, it is seen the frequency/percentage statistics are given in only 32 studies (28.57\%), average/standard deviation statistics are given in only 2 studies (1.79\%), graphical representation are given only in 43 studies (38.39\%). Both frequency/percentage statistics and mean/standard deviation statistics are $7(6.25 \%)$ while the number of surveys with frequency/percentage statistics and graphical representation is 25 . Mean/standard deviation and graphical representation are not included in any study but 3 (2.68\%) studies are used in all three descriptive statistics. The graphical distribution of the descriptive statistics that used in the articles has been shown in. Distribution of descriptive statistics used in the articles is shown in graphic of Figure 10. 


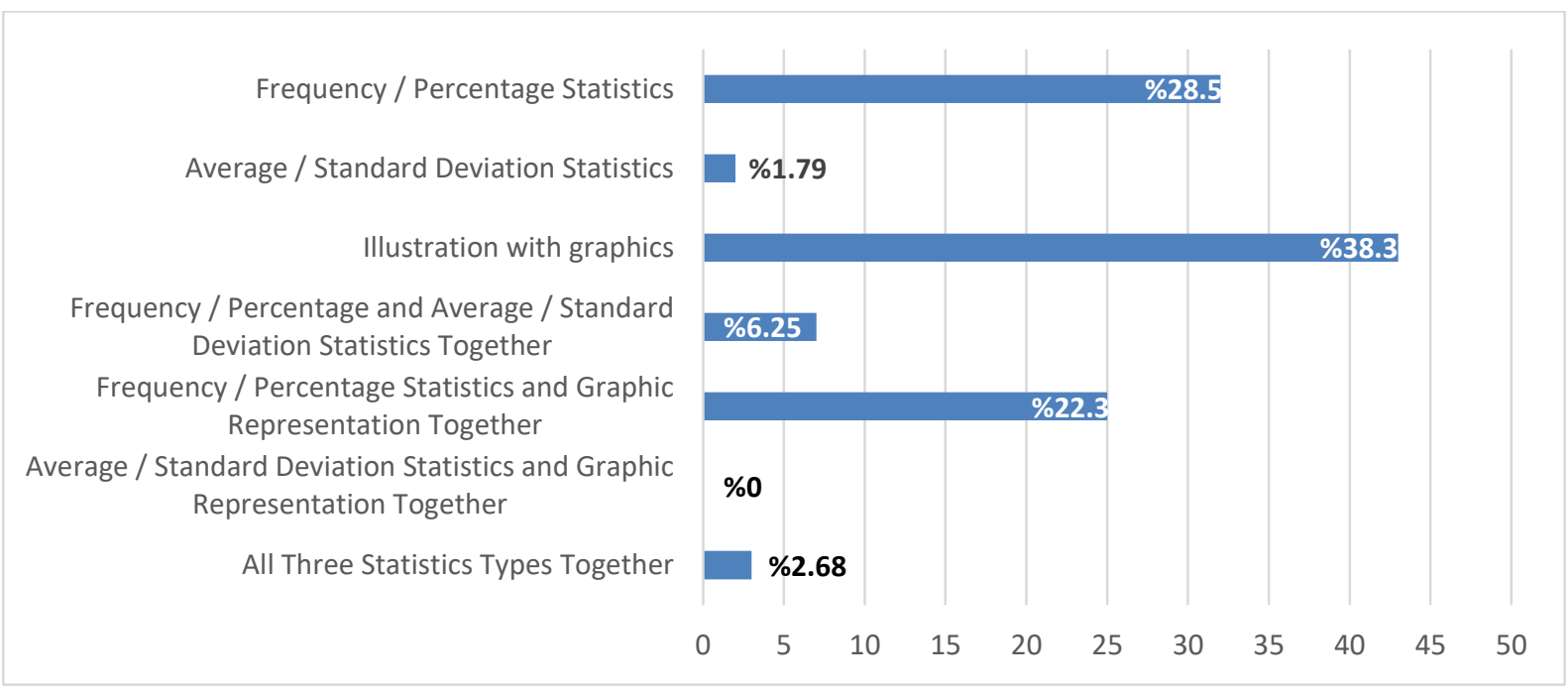

Figure 10. Distribution of descriptive statistics used in the articles

Out of $152(51.17 \%)$ articles that used quantitative data analysis method, 86 articles use predictive statistics. When these methods are analyzed it has been seen 19 times correlation analyze (22.35\%), 23 times t-test $(27.06 \%)$, 20 times Anova/Ancova analyze (23.53\%), 4 times (4.71\%) Manova/Mancova analysis, 17 times factor analysis (20\%), 28 times regression analyse (32.94\%), 9 times (10.59\%) analysis that are not parametric, 31 times predictive statistics (36.47\%) is used. Distribution of predictive statistics used in articles is shown in graph of Figure 11.

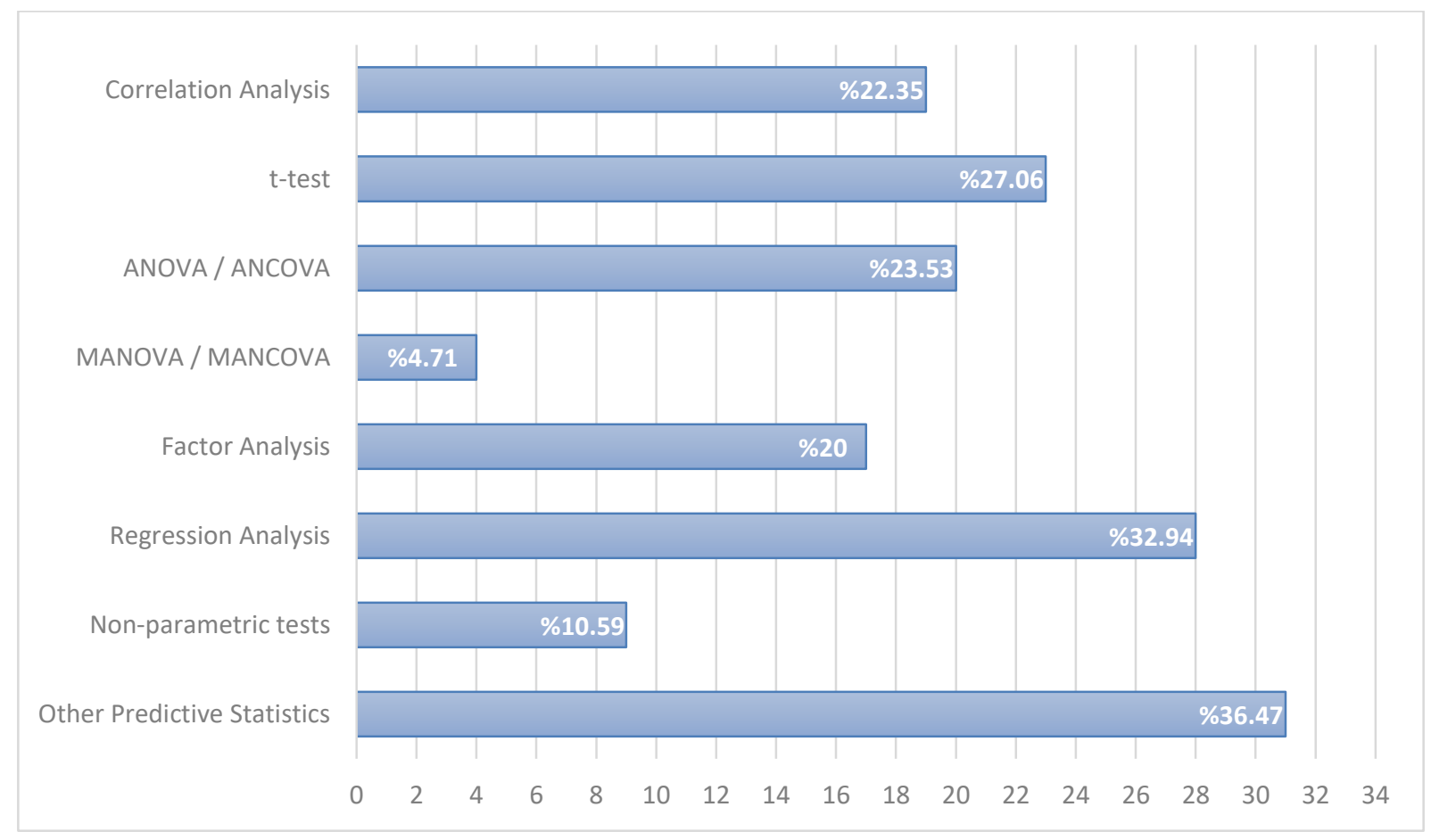

Figure 11. Distribution of predictive statistics used in articles 


\section{Distribution of Data Collection Tools Used in the Articles}

When the articles are analyzed in terms of data collection tools, 269 studies (90.57\%) has been found at least one data collection tool. The number of articles that is studies without using any data collection is $28(9.43 \%)$. When the collection tools are analyzed as studies are carried out, the number of studies that are observed is 9 $(3.03 \%)$, the number of studies that are interviewed is $40(13.47 \%)$, the number of studies that used scales is 30 $(10.10 \%)$, the number of studies that used questionnaires is $68(22.90 \%)$, the number of studies that made use of the documents is $101(34.01 \%)$ and the number that are used data collection tools that are except those or the number that created its own data collection tool is $91(30.64 \%)$. Distribution of data collection tools that articles used is shown in the graphic of Figure 12.

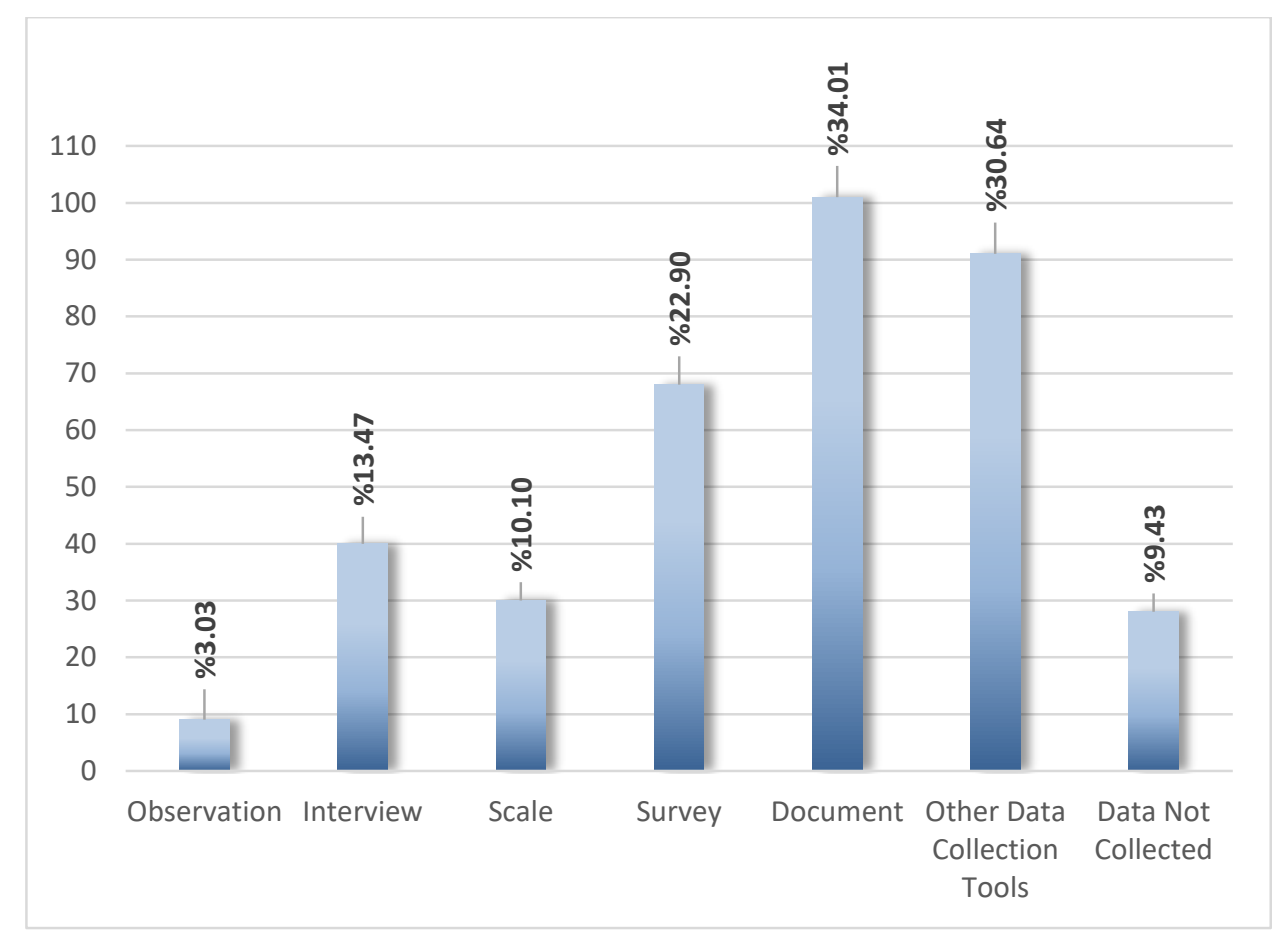

Figure 12. Distribution of data collection tools that articles used

\section{Distribution of the Participants in the Articles to the number of Articles}

The number of articles, their participants are mentioned, on the scope of the study are $101(34 \%)$. In these 101 articles, distribution of participants to the number of articles is has been shown on Figure 13. 


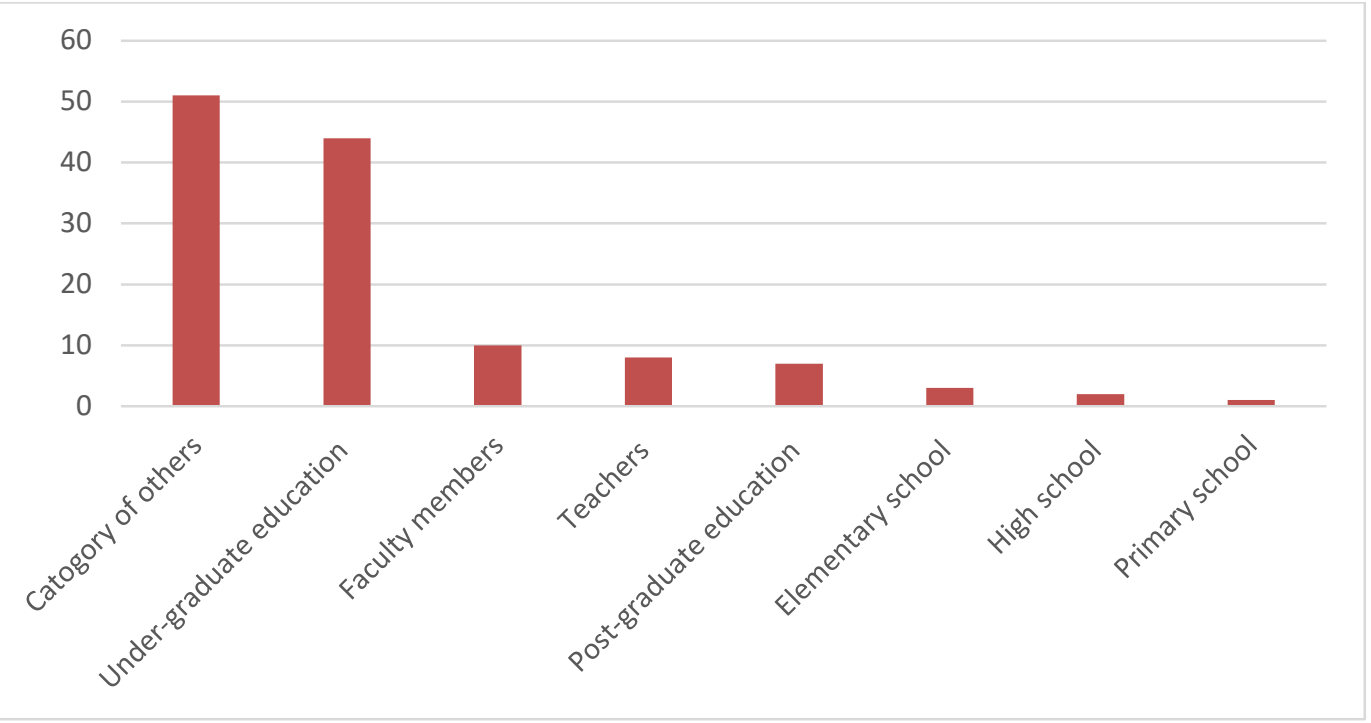

Figure 13. Distribution of participants to the number of articles

According to the data in Figure 13, 51 (50.5\%) of the articles that mentioned those who participated in studies also included in other studies with participants in the "category of others". In this category, there are people from different profession groups such as employed or non-employed individuals, professional captains, persons with various types of ship using license, doctors, nurses, pharmacists, adults, government and representatives of semiofficial organizations, policy-makers, managers, sports trainers, psychiatrists, visually impaired musicians, companies, school and office workers, vets, dentists. After the other participants' category, it is category of undergraduate education students with 44 articles. Afterwards, respectively, faculty members included in 10 articles (9.9\%), teachers in 8 articles $(7.9 \%)$, students of post-graduate education in 7 articles $(6.9 \%)$, students of elementary school in 3 articles (3\%), students of high school in 2 articles (2\%), students of primary school in 1 articles $(1 \%)$. In the light of these findings, it can be said that studies on lifelong learning field are conducted mostly on working individuals or individuals who are prepared for working life and it can be said that the individuals who are in pre-university education are quite rare in this field.

\section{Distribution of the Participants in the Articles by the Age}

In the articles searches within the scope of the study, it has been seen 49 articles mentioned the age groups of participants. The age groups mentioned in these 49 studies are divided into 9 age groups that are " $0-5$ " years, " 6 8 " years, "9-14" years, "15-18" years, "19-30" years, "31-40" years, "41-50" years, "51-60" years and "61 and above" and total 146 groups has been found out. There are no articles in this group with $0-5$ age group (n=0\%). It has been seen there are 2 groups in "6-8 age range", 3 groups in "9-14 age range", 6 groups in "15-18 age range", 31 groups in "19-30 age ranges", 32 groups in "31-40 age range", 27 groups in "41-50 age range", 25 groups in "51-60 age ranges", 18 groups in "61 and above age range". According to these obtained results, it has been observed that there are 102 groups (69.86\%) over the age of 31 and 44 groups $(30.14 \%)$ below the age of 30 . The graph showing the distribution of the participants to the age is shown in Figure 14. 


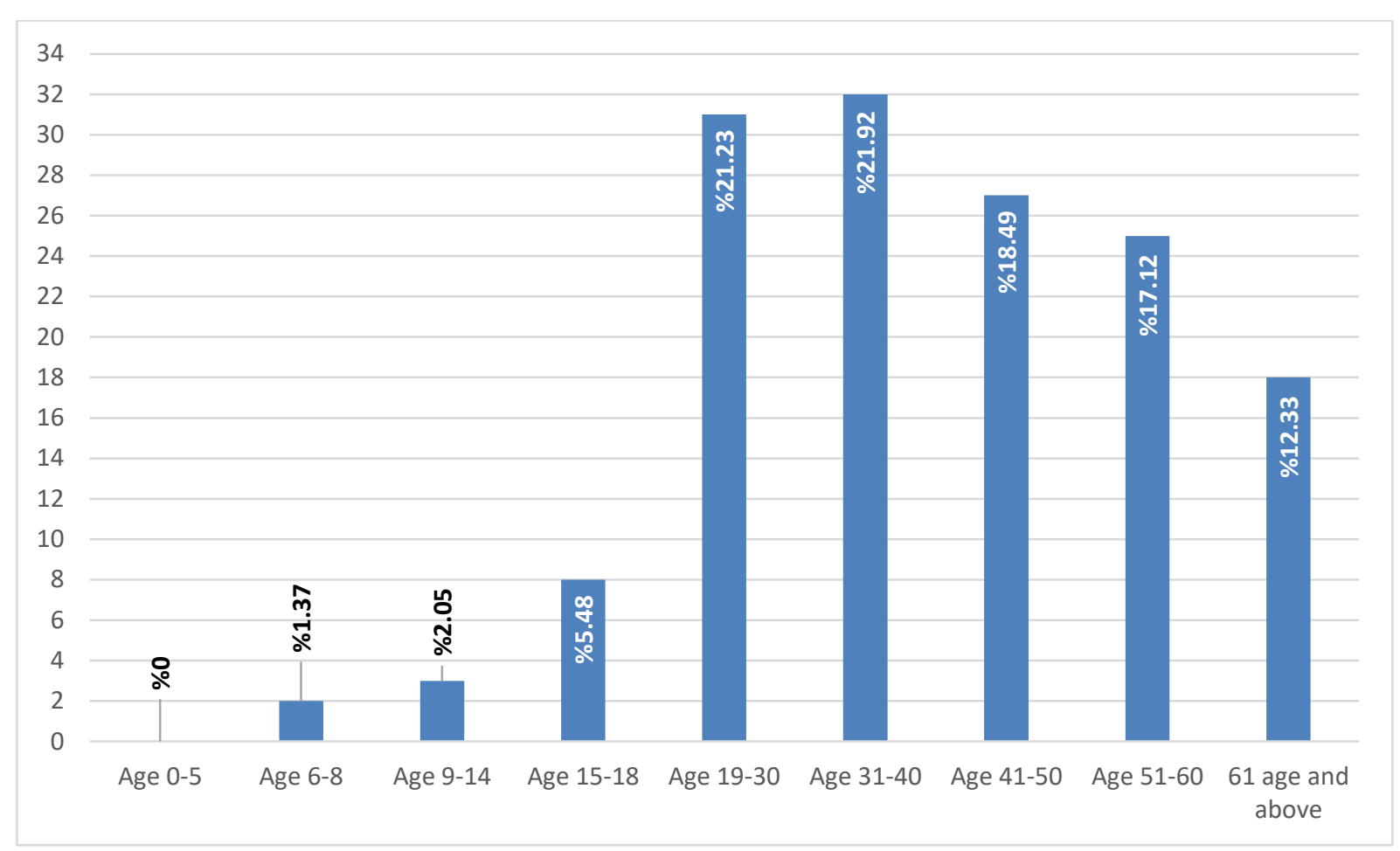

Figure 14. The distribution of the participants to the age

\section{Distribution of Sample Sizes Specified in the Articles}

Out of the 297 articles analyzed in this study, 127 (49.76\%) sample sizes are specified. Size of these samples are analyzed under 6 groups which are "1-10 participants", "11-30 participants", “31-100 participants", "101-300 participants", "301-1000 participants" and "more than 1000 participants. 10 studies (7.87\%) analyzed with 1-10 participants, 21 studies (16.54\%) analyzed with 11-30 participants, 18 studies $(14.17 \%)$ analyzed with 301-100 participants, 30 studies analyzed with 101-300 participants (23.62\%), 23 studies (18.11\%) analyzed with 301-1000 and 25 studies $(16.69 \%)$ are analyzed with more than 1000 participants. 78 studies are analyzed with 101 participants $(61.42 \%)$. The graph showing the distribution of sample sizes is given in Figure 15 . 


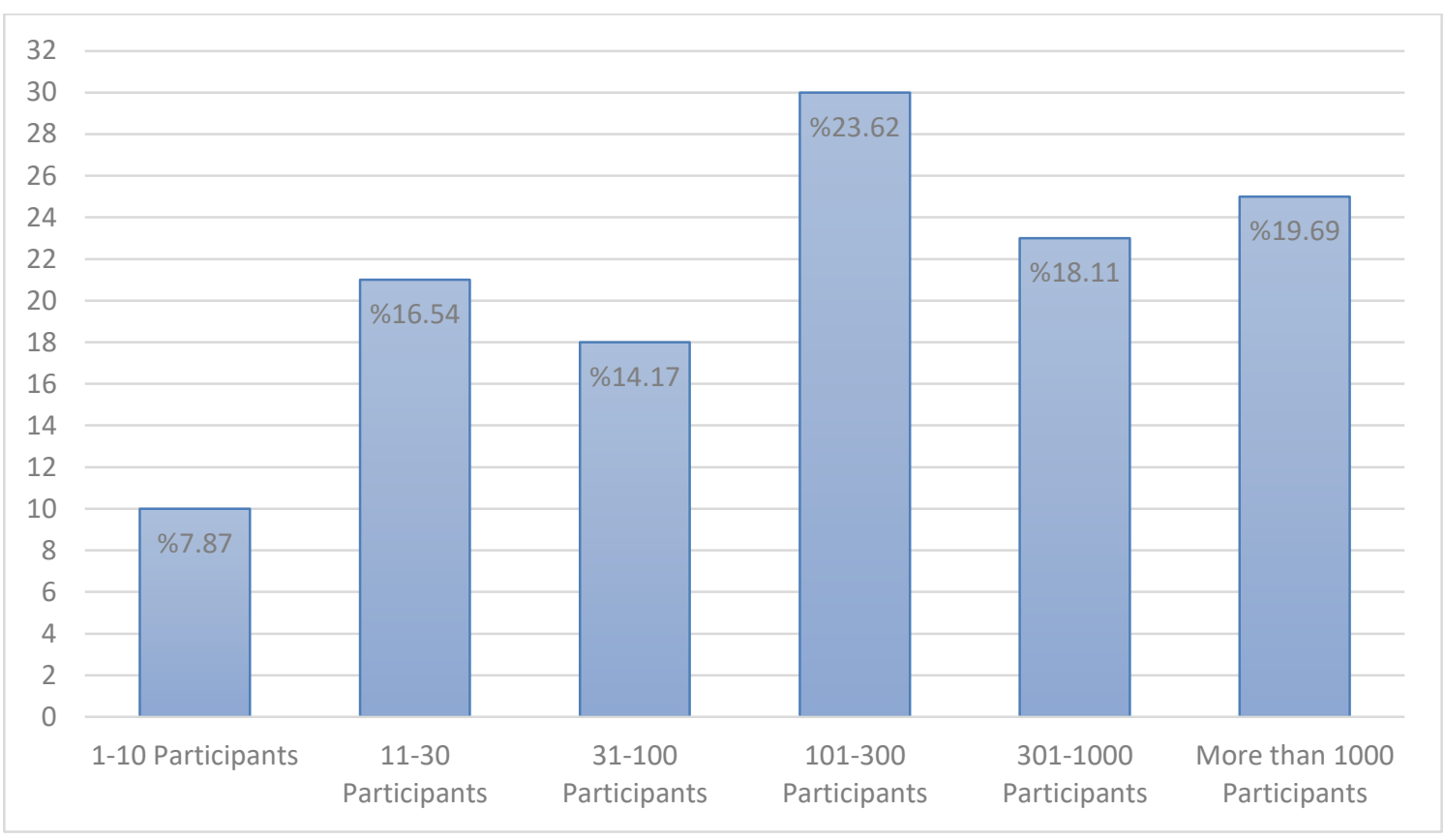

Figure 15. The distribution of sample sizes

\section{Distribution of Key Words in Articles}

In $82(27.61 \%)$ of 297 articles analyzed within the scope of the study are not specified any keyword. When 215 articles $(72.39 \%)$ are analyzed, it has been found out that 774 different words are used 1230 times. In these words 1 word 120 times $(9.76 \%), 1$ word 12 times $(0.98 \%), 1$ word 11 times $(0.89 \%), 1$ word 10 times $(0.81 \%), 2$ words 9 times $(0.73 \%), 1$ word 8 times $(0.65 \%), 5$ words 6 times $(0.49 \%), 2$ words 5 times $(0.41 \%), 8$ words 4 times $(0.33 \%), 15$ words 3 times $(0.24 \%), 49$ words 2 times $(0.16 \%)$ and 688 words 1 times $(0.08 \%)$ have been used. The graph showing the numerical distribution of the keywords mentioned in the articles is given in Figure 16. 
Number of Repeats

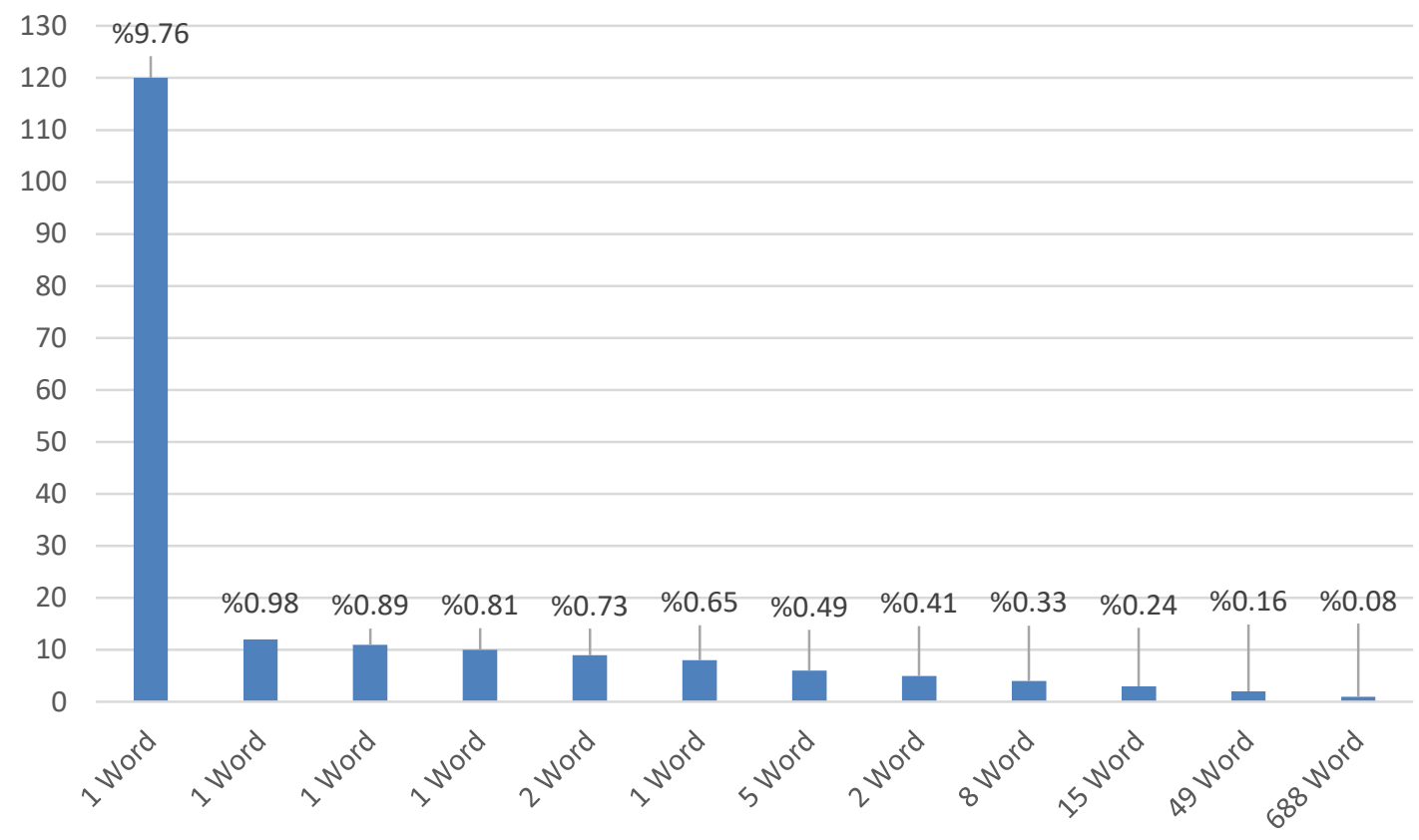

Figure 16. The numerical distribution of the keywords mentioned in the articles

The most used word among the key words is "Lifelong Learning" ( $\mathrm{n}=120,9.76 \%)$. The most used word among the key words is "Lifelong Learning" $(\mathrm{n}=120,9.76 \%)$. Apart from this, the most used word is "Adult Education" $(\mathrm{n}=12,0.98 \%)$, "Life-long Learning" ( $\mathrm{n}=11,0.89 \%)$, "Education" ( $\mathrm{n}=10,0.81 \%)$, "Learning" and "Continuing Education" ( $\mathrm{n}=9,0.73 \%)$. The graph of the top 5 keywords used in the articles is given in Figure 17.

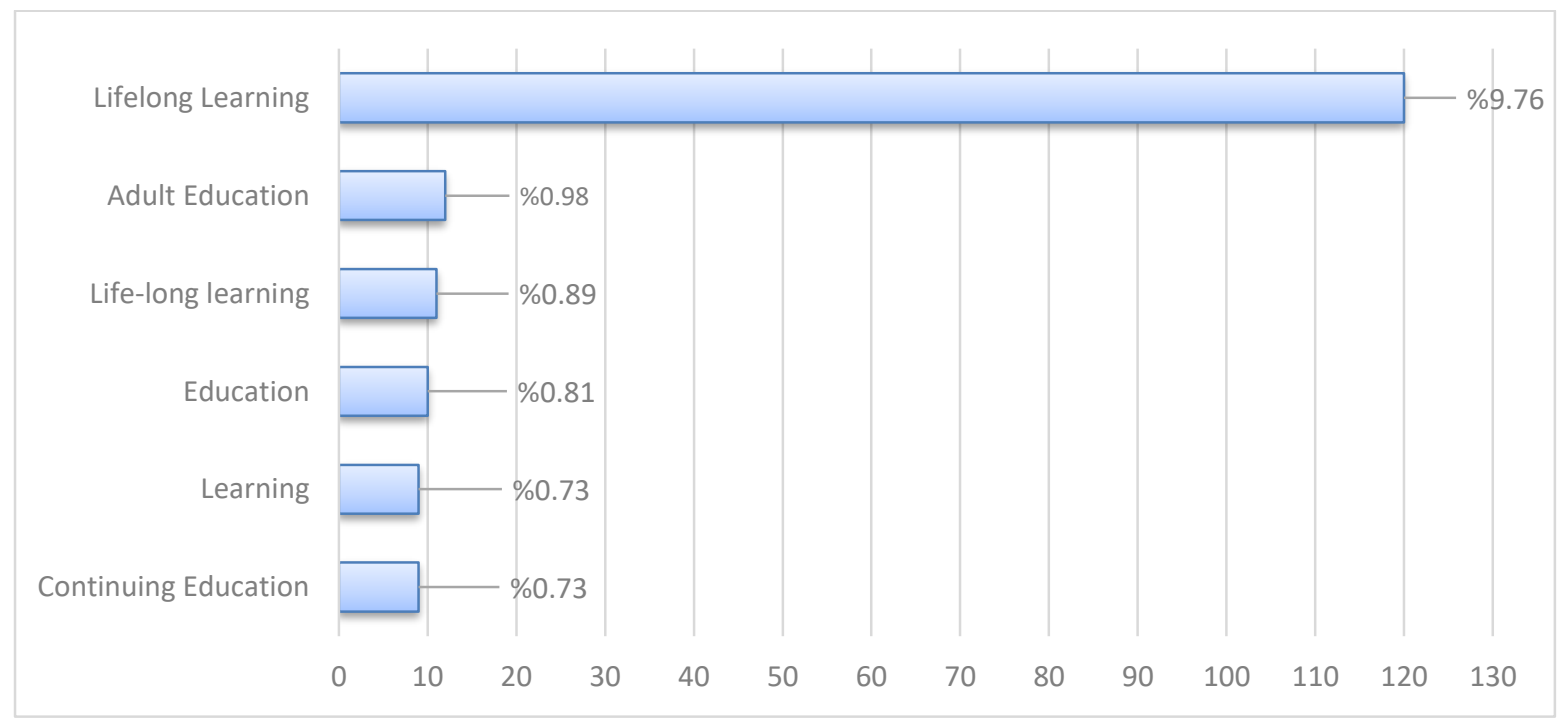

Figure 17. Top five keywords used in the articles 


\section{Discussion and Conclusion}

Learning is not something we do in people's daily life; it is the center of anything we do in daily life as productive people. Improving learning is one of the most important activities individuals, policy makers and governments need to invest in (Wagner, 2015). That is why lifelong learning has been one of the most popular fields of interest in recent years (Kabataş \& Karaoğlan Yılmaz, 2018). One of the most important reasons for this is the complexity of today's society- with the dynamic and ever-changing information, the mass use of internet, multimedia and educational technology- has demand for a more flexible workforce and has ever- changing labour market. In order to overcome this complex structure, societies tend to engage in lifelong learning and work more intensively in this field (Dochy, Segers, Van den Bossche, \& Gijbels, 2003). It is very important that people improve lifelong learning skills and be aware of this every time to keep up with the world we live in. Lifelong learning is primarily aimed at closing the difference between the constantly updated requirements of human life and the new information that is increasing day by day. New technological developments, new formations and structuring that we encounter in daily life expects the individual to renew himself/herself and to increase his/her existing knowledge. All these circumstances don't let individuals live with the education he/she receives only from the school (Topakkaya, 2013). To be able to exist in today's business world based on economy, to be able to work in daily life, to keep up with the constantly developing technology world depends on the lifelong learning skills of individuals. To be able to acquire and develop these skills, the renewal and development of education systems, methods or materials is highly dependent on the quality of the work to be done in this field (Sezer, Karaoğlan Y1lmaz, \& Y1lmaz, 2017). From this point, in line with its purpose of the study, the articles that were obtained from the search results of the SCI-Expanded, SSCI and A\&HCI citation indices in the Web of Science between January 2007 and December 2017 were analyzed in the context of the journals they were published, the languages they were written, the methods used and the participants.

According to the findings obtained from the study, it has been observed that studies on lifelong learning field have been published in many different journals. The publication of 297 articles in 205 different journals is a sign of the diversity of academic journals. At the same time, the large number of academic journals shows that academic studies have big interest in lifelong learning. However, in the diversity of so many academic journals. There are very few academic journals published in Turkey $(n=5)$. That there aren't not so many departments on lifelong learning in universities in Turkey, this subject has been just recently finding place in different occupational departments' courses, insufficient number of post-faculty graduates in this field can be said as reasons for these. Council of Higher Education has started to show interest in this issue especially after 2005 and in recent years, it has tried to bring the issue to the agenda of academics (Topakkaya, 2013). The concept of lifelong learning is not widespread, as well as not a new concept for Turkey and carried out quite far from the present existing conditions (Tasçı et al., 2015). When the growing interest of Europe since 1900s is taken into consideration, it is possible to say Turkey is coming back. To the distribution of the languages of articles they are written, almost all of the articles are written in English (90.9\%). The reason for this is that in all parts of the world, the most preferred common language is English compared to other languages. People prefer English as a second language other than their mother tongue. English is today the common language of the world of technology and science, and it continues to be an increasingly common communication language in almost every field (Smith, 2015). It is natural for scientists to want to write their work in a language that everyone can understand, and to choose the English, common language of communication that almost all countries use. The number of articles written in Turkish is 7 (2.4\%). Turkish is ranked 3rd in 9 languages. It can be said that the growing interest on lifelong learning field is higher than other countries. Thesis related to this field in Turkey has started in 2007, it is improvement has been gaining more importance nowadays. However, this interest has not been not yet at the desired level (Yenen et al., 2016). More studies are needed in this field and it should contributed to the literature.

In the articles analyzed in line with the purpose of this study, qualitative methods are preferred more than other study methods. When the used study methods are analyzed, it can be said qualitative methods are used in more than half of all studies (62.3\%). Qualitative study follows a process for realizing events in a realistic and holistic manner in their natural environment, in other words, it is studies that connecting social phenomena with the environment that they are in; understanding and studying it foregrounding like that (Yıldırım \& Şimşek, 2016). Lifelong learning is actually a process rather than an outcome. It is fact that observation and monitoring them takes a long time (Yenen et al., 2016). For these reasons, qualitative study methods may be preferred more than other methods in studies related to the field of lifelong learning. When looked at the methods of articles, published in Turkey, it can be concluded that qualitative and quantitative methods are preferred at the same number. Similarly, 
Yenen, Kılınç and Bulut (2016) analyzed the thesis on lifelong learning and found out that both quantitative and qualitative methods were used in equal numbers. However, they did not drop a cross any experimental study in their theses.

Articles that are analyzed in the scope of study are written in 9 languages. Qualitative data analysis methods are the most preferred data analysis methods among the data analysis methods used in the articles. While there are 10 articles $(3.37 \%)$ no data analysis are used, 135 articles $(45.45 \%)$ used in qualitative data analysis and 89 articles (29.97) are used in quantitative data analysis method. The number of articles using both data analysis methods is $63(21.21 \%)$. Qualitative data analysis methods are used in 198 studies $(66.66 \%)$ and quantitative data analysis methods are used in 152 studies (51.17\%). These results demonstrates the support the methods used in articles, qualitative data analysis methods are more preferred in process-oriented subjects such as lifelong learning. At the same time, the number of articles that use both quantitative data analysis and qualitative analysis methods together can be interpreted as the indicator of a defect for this issue. The combined use of different data analysis methods together is important in order to analyze the data correctly and to obtain stronger results (Göktaş, et al., 2012). The combination of both quantitative and qualitative data analysis methods will make the results stronger (Çakmak, et al., 2016; Gülbahar \& Alper, 2009). The use of different data analysis methods together in the next studies can be recommended to eliminate this deficiency. When the qualitative data analysis methods are analyzed in itself, it can be said that descriptive data analysis methods are more preferred than other qualitative data analysis methods $(n=102,51.52 \%)$. As a reason for this, it can be said that descriptive data analysis can be made carried out easier than other methods in qualitative data analysis methods. When the quantitative data analysis methods are analyzed in itself, it is seen that articles that only use the descriptive statistics that are more preferred than the articles which only use predictive statistics. Likewise, descriptive statistics can be carried out easier than predictive statistics.

While in descriptive statistics graphic demonstration $(n=43,36.39 \%)$ and frequency percentage $(n=3228.57 \%)$ are prominent, in predictive statistics regression analysis came the fore. In terms of data collection tools, almost all of the studies used at least one data collection tool $(n=269,90.57 \%)$. Data were collected from the documents in these data collection tools $(\mathrm{n}=101,34.01 \%)$. Among these data collection tools, mostly from the documents data were collected. Among these data collection tools, mostly from the documents data were collected $(\mathrm{n}=101$, $34.01 \%$ ). This result supports the methods used in the articles and the data analysis methods used. There are also a lot of articles $(n=91,30.64 \%)$ that make up and use their own data collection tool. In the process of evaluations, it can be said that the studiers create their own data collection methods and it is quite common for them to develop or update these tools according to the process. These two data collection tools are followed by questionnaires $(n=68,22.90 \%)$. These results contradict the results obtained by Çakmak et al., (2016) and Gülbahar and Alper (2009). In the studies, it is concluded that the questionnaires are the most widely used data collection tool. The reason why the results of this study is different may be interpreted as studies in different fields need different data collection tools. In the majority of articles, there are no participants. The number of the participants is $101(34 \%)$. Almost half of the participants are different occupational groups or individuals with different tasks $(\mathrm{n}=51,50.5 \%)$. Language students, lecturers, post faculty education students $61(60.4 \%)$. From this point of view, it is seen that individuals who are in contact with universities take part in studies related to the field of lifelong learning. It is possible to say that individuals attending pre-university education have the least participation in this field. Secondary, junior high school and primary school students are included in 6 articles (6\%). Lifelong learning with more adult education can be a factor in the emergence of these results. However, lifelong learning is a very broad field. It is important to provide lifelong learning skills to individuals at an early age. In this context, it is also very important to conduct further study on individuals who attend pre-university education. When the distribution of the participants according to age was analyzed, it is found that there are very few studies indicating the age of the participants $(n=49,16.49 \%)$. When the participant ages mentioned in these studies are grouped, it is seen that there are a total of 146 groups and the majority of the participants aged 30 years or older $(n=102,69.86 \%)$. The reason for this is that the field of lifelong learning is interpreted by studiers as an area for adults. Older individuals may have been preferred as participants in these studies to measure the success of educational policies. However, lifelong learning is not just an adult-oriented field. Lifelong learning skills are a type of skill that should be acquired at an early age (Budak, 2009). It is evident that studies on lifelong learning should focus more on younger age groups. More data can be obtained on how to acquire lifelong learning skills through active studies on active individuals in formal education and contribute to the development of educational policies. The sample size of the articles is $127(49.76 \%)$. More than half of these studies were conducted with 101 participants $(n=78,61.42 \%)$. Study mostly conducted with 101-300 people $(n=30,23.62 \%)$ and secondly studied with 1000 or ore participants $(n=25,16.69 \%)$. In parallel with these results, Bozkaya, Aydın and Kumtepe (2012) found out in their study that 
the majority of the studies with more than 200 participants are carried out. However, Çakmak et al., (2016) and Göktaş et al. (2012) found that the results they obtained in their studies that in the studies smaller sample sizes preferred. This difference may also arise from the difference between the mentioned study fields. Findings from large sample groups provide more general results (Bozkaya, Aydın, \& Kumtepe, 2012). It is possible to say that larger sample groups are preferred in studies conducted in the field of lifelong learning since the results that address the general public in the field of education policy may be more useful. When the keywords used in the articles are considered, it is seen that the "Lifelong Learning" keyword is used the most. However, other words apart from this keyword are almost non-existent. Accordingly, the field of lifelong learning can be interpreted as a field of study that can be associated with almost every field.

As a result, the diversity of the journal published in the field of lifelong learning is numerous but among those journals, the number of those which are published in Turkey is few, while articles are written, English is the language that mostly preferred, as method qualitative method is the mostly preferred, as data analysis method the descriptive method is the mostly used, wide variety of samples chosen by participants, with adult age groups studied more, sample size is usually large and mostly "Lifelong Learning" keyword used most. In the literature, there has been seen no studies analysing the articles related to the field of lifelong learning. In this study, articles related to the field of lifelong learning have been analyzed according to certain variables and suggestions have been conducted to give an idea about the future studies.

Lifelong learning is a field that has been gaining growing interest in Turkey. In this respect, it is advisable to conduct further study and to contribute to the literature. Giving more space to studies on educational publishing in Turkey on lifetime of journals, researchers can encourage them to do more studies related to the field in question. As well as studding on different types of samples, deficiencies in this field can be eliminated by studying with individuals especially pre-university students. Content analysis or meta-analysis studies on lifelong learning are not common. Further studies in this field is crucial for understanding lifelong learning and for guiding future studies. 


\title{
Hayat Boyu Öğrenme Kapsamında Son 10 Yıl İçerisinde Yayınlanan Makalelerin Betimsel Analizi
}

\author{
Giriş
}

Dünya tarihine bakıldığında sürekli bir değişim ve bir gelişim görmek mümkündür. Yaşayan varlıklar, meydana gelen değişimlere her zaman ve her dönemde adapte olurlar. Biz insanlar da hem çevremizi değiştirir, hem de kendimiz değişiriz. Özellikle son yüzyıl içerisinde yaşanan gelişmeler, dünyadaki var olan bilginin katbekat artmasına katkıda bulunmuştur. Bilginin artması ve sürekli değişim içinde olması, biz insanları güncel kalmak ve sürekli öğrenme eğiliminde bulunmak zorunda bırakmaktadır. Yaşanan bu gelişmeler, toplumları bilgi toplumuna dönüşmeye zorlamaktadır. Bu dönüşüme ayak uydurabilmek için ise bireyler sürekli öğrenmeye ihtiyaç duymaktadırlar. İnsanlar mesleki yaşamlarında kalıcı olabilmek, günlük hayatlarında çağın gereksinimlerini karşılayabilmek ve hatta kendi çocuklarıyla çağın dilini konuşabilmek adına sürekli öğrenmek ve kendilerini geliştirmek zorundadırlar. Hayat boyu öğrenme kavramı tam da bu noktada, bu ihtiyaçları gidermek adına karşımıza çıkar. Hayat boyu öğrenme, insanların doğumlarından ölümlerine dek, yaşantılarından, çevrelerinden veya herhangi bir yerden edindikleri bilgi, beceri veya tutumları içinde yaşadıkları zamanın gerekliliklerine göre güncelleyebilmeyi vurgulamaktadır (Ayçiçek, 2016). Hanemann (2015) hayat boyu öğrenmenin yalnızca formal eğitimde değil, özellikle dezavantajlı durumda olan veya resmi olarak bir eğitim almayan kişiler için bir zorunluluk haline geldiğini belirtmektedir.

Avrupa Komisyonu (2000) hayat boyu öğrenmeyi bilgi, beceri ve yetkinliği geliştirme amacıyla sürekli olarak üstlenilen bütün amaçlı öğrenme faaliyetleri olarak tanımlanmaktadır. Raporda bireylerin aktif birer vatandaşa dönüştürülmesini teşvik etmek ve istihdam edilebilirliğin artırılması adına hayat boyu öğrenmenin önemine vurgu yapılmıştır. Avrupa'daki mevcut ekonomik ve sosyal değişimin sonucu olarak eğitime temelde yeni bir yaklaşımın getirilmesi gerekliliği vurgulanmış olup, her türlü öğretim ve öğrenimin bir araya getirilmesi gerektiği belirtilmiştir. Küreselleşmenin sonucu olarak sınırların ortadan kalkmasıyla oluşan bu yeni düzende, ülkeler yeniden yapılanma sürecine girmiş bulunmakta ve bu hızlı değişim ve gelişimin bütün alanlara yansımasının sonucu olarak var olan klasik eğitim anlayışı, yerini gelişen teknolojilerle ve yeni nesil bireylerle uyumlu eğitim programlarını geliştirme yaklaşımına doğru değişmektedir. Bu nedenle, eğitim sistemlerinin sürekli geliştirme ve niteliğini arttırma arayışı içine girilmiştir. Günümüz bireylerinin hayat boyu öğrenme alışkanlıklarını kazanabilmeleri adına, hemen her ülke eğitim politikalarında değişiklikler yapmakta ve eğitim sistemlerini bu yeni bilgi düzenine adapte etmeye çalışmaktadırlar. Bir başka deyişle ülkeler artık eğitim sistemlerini hayat boyu öğrenme politikalarıyla birlikte yapılandırmaya ihtiyaç duymaktadır.

Geçmiș dönemlerdeki hayat boyu öğrenme uygulamalarını göz önüne aldığımızda akla ilk gelen uzaktan eğitim çalışmaları olmaktadır. Uzaktan eğitim geleneksel öğrenme - öğretme ortamlarının getirmiş olduğu sınırlılıkların ortadan kalktığı, ögreticiler ve öğrenenler arasındaki iletişim ve etkileşimin özel olarak hazırlanmışş çeşitli ortamlar yoluyla sağlandığı bir öğretim yöntemidir (Alkan, 1987). Uzaktan eğitim sistemleri ile hangi yaşta ve düzeyde olursa olsun hemen herkes eğitim hizmeti alabilmektedir (Gelişli, 2015). 1700’lü ylllarda Amerika'da mektup yoluyla başlayan, ardından yazılı ders materyallerinin postayla gönderilmesi ile devam eden sistem, uzaktan eğitim uygulaması sayılabilecek ilk uygulamadır (Ergüney, 2015). Basılı materyallerin mektuplaşma/posta yoluyla kişilere gönderildiği uygulamalar uzaktan eğitimin en eski biçimi olarak kabul edilebilir (Gelişli, 2015). Günümüze yaklaştıkça radyo ve televizyon yayınları ile çeşitlenen uygulamalar, görsel ve işitsel içeriğin yeni medyayla birlikte dijitalleşmesine bağlı olarak uzaktan eğitim sistemlerine oldukça alternatif firsatlar sunmaya başlamışıır (Atik \& Ata, 2018). Bilgisayar ve internet teknolojilerinin eğitim uygulamalarına yeni kapılar açmasıyla dijital uzaktan eğitim platformları bireylerin daha çok ilgisini çekmeye başlamıştır. Dijital platformlar kişilerin kendi kendine öğrenmesini destekleyen yapısıyla hem eşzamanlı hem de eşzamansız eğitim olanağı sunar. $\mathrm{Bu}$ da bireylerin kendi eğitimlerini planlamalarına olanak sağlar. Son yıllardaysa mobil teknolojiler uzaktan eğitim uygulamaları olarak oldukça yaygın bir şekilde kullanılmaya başlamışıı. Bu araçlar bilgisayarlara göre daha kolay erişilebilir ve ucuzdur (Karaoğlan Yılmaz, Dilen, \& Durmuş, 2018; Oran \& Karadeniz, 2007). Mobil öğrenme uygulamalarıysa kişilerin gereksinimlerine göre değişebilmektedir. Mesleğe yönelik yetiştirme ve kullanıcı performansı geliştiren mobil performans destek sistemleri, uyarı ve bildiri niteliğindeki mobil destekli uygulamalar, kullanıcıların kendilerini değerlendirmelerine yönelik hazırlanan testler ve alıştırmalar, hem eğlence hem de öğrenmeye yönelik oyun ve simülasyonlar, etkileşim ve iş-birliğini destekleyici danışmanlık ve rehberlik hizmetleri gibi uygulamalar günümüzde mobil cihazlar üzerinden gerçekleşmektedir (Özdamar Keskin, 2010). Gelişen teknolojilerle birlikte hayat boyu öğrenme uygulamaları da değişmektedir ve gelişmektedir. Sürekli 
geliştirilebilir ve gelecek nesillerin eğitim ihtiyaçlarını karşılayacak yeterlikte olan bu yeni nesil sistemler, bireylerin hayat boyu öğrenen bireyler haline gelmelerinde büyük bir rol oynamaktadırlar.

Hayat boyu öğrenme becerilerinin kazanılması süreci erken yaşlarda bireye kazandırılmalıdır. Hayat boyu öğrenme; bireysel, sosyal veya istihdam ile ilişkili bir bakış açısı ile bilgi, beceri ve bireyin sahip olduğu potansiyeli geliştirmek amacıyla insanların hayatları boyunca yerine getirmeye çalıştı̆̆ her türlü öğrenmeyi kapsamaktadır. Hayat boyu öğrenme, yaşamın tüm alanlarına, yaşa, dine, cinsiyete, rrka veya sosyal, ekonomik statüye bakılmaksızın aktif olarak katılım sağlayabilen bütün bireylerin toplumda yer almasını amaçlamaktadır (Aksoy, 2008). Bundan dolayı eğitimin her düzeyinde hayat boyu öğrenme etkinliklerinin yerleştirilmesi ve bireylere erken yaşlarda bu kazanımların verilmesi çok önemlidir. Hayat boyu öğrenme kavramının toplumlar açısından ne kadar önemli olduğunu tekrar vurgulamak gereklidir. Çünkü özellikle son birkaç on yıldır birçok ülkede hayat boyu öğrenme kavramı hakkında araştırmalar yapılmakta ve bu kavram ile bütünleşecek şekilde yeni yapılanma çalışmaları yapılmaktadır. Sınırların ortadan kalktığı, ekonomik düzenin hâkim olduğu günümüzde bütün toplumlar, mevcut ülkeler arası rekabette tutunabilmek adına hayat boyu öğrenme kavramını daha iyi anlamalı ve mevcut sistemlerine uygun olacak şekilde adapte edebilmelidir ve hatta gerekiyorsa sistemlerini güncellemelidir.

Toplumların değişen yapısı ve gelişen teknolojilerle birlikte hayat boyu öğrenme uygulamalarının da geliştirilmesi, alanla ilgili yapılacak araştırmaları daha da değerli hale getirmektedir. Yapılacak olan araştırmalar bu uygulamaları geliştirmek ve bireylerin ihtiyaçlarını istenilen ölçüde karşılamak için gerekli düzenlemeleri veya ihtiyaçları ortaya koyacaktır. Sürekli bir değişim içinde olan yeni dünya düzeninde üretilen bilgi miktarı katbekat artmakta dolayısıyla bireylerin ihtiyaçları da bu oranda hemen her gün değişmektedir. Teknolojiler bir yandan bireylerin bilgiye ulaşmasını kolaylaştırırken diğer yandan bireyleri sürekli öğrenmeye ve kendilerini geliştirmeye zorlamaktadır. Bu değişimle birlikte var olan meslek dallarının sürekli güncellenmesi ve ortaya çıkan yeni meslek grupları kişilerin kendilerini güncel tutmaya ve devamlı bireysel becerilerini geliştirmeye yönlendirmektedir. Var olan bu düzende hayat boyu öğrenmenin bireyler açısından önemi ortadır (Binay Eyüboğlu \& Karaoğlan Yılmaz, 2018). Hayat boyu öğrenme alanı ile ilgili yapılan araştırmalar son yıllarda daha da çoğalsa da, alanda yazılan makaleleri analiz ederek derleyen bir çalışmaya pek rastlanmamaktadır. Belirli bir konunun araştırılması noktasında konuyla ilgili alanda yapılan çalışmaların eğilimlerinin ve bu çalışmalarının hangi yönde ilerlediğinin ortaya konmasında en etkili yöntem bu alanda yürütülen çalışmaları analiz etmektir (Yenen ve diğerleri, 2016). Bu tür çalışmalar belirli ölçütler dâhilinde ve belli bir zaman aralığında sistematik bir şekilde yapıldığı zaman, araştırma konusuyla ilgili genel bir çerçeve çizmede ve alanda çalışacak araştırmacılara fikir sahibi olmaları açısından büyük önem arz etmektedirler (Bıkmaz, Aksoy, Tatar, \& Altınyüzük, 2013). Buradan hareketle, hayat boyu öğrenme konusuyla ilgili Ocak 2007 - Aralık 2017 yılları arasında Web of Science'da yayınlanan makalelerin analiz edilmesi amaçlanmıştır. Bu araştırmayla birlikte hayat boyu öğrenme ile ilgili yapılan çalışmaların bir araya getirilmesinin önemli bir bilgi birikimi oluşturması ve alandaki boşluğu doldurması beklenmektedir. Araştırmanın genel amacından hareketle aşağıdaki sorulara yanıt aranmıştır:

1- Makalelerin yayınlandıkları dergilere göre dağılımı nasıldır?

2- Makalelerin yazıldıkları dillere göre dağılımı nasıldır?

3- Makalelerde kullanılan yöntemlerin dağılımı nasıldır?

4- Makalelerde kullanılan veri analiz yöntemlerinin dağılımı nasıldır?

5- Makalelerde kullanılan veri toplama araçlarının dağılımı nasıldır?

6- Makalelerde belirtilen katılımcıların oranları nelerdir?

7- Makalelerde belirtilen katılımcıların yaşa göre dağılımları nasıldır?

8- Makalelerde belirtilen örneklem boyutlarının dağılımı nasıldır?

9- Makalelerde belirtilen anahtar sözcüklerin dağılımı nasıldır? 


\section{Yöntem}

\section{Araştırma Modeli}

Bu çalışma tarama modeli kullanılarak hazırlanmıştır. Tarama modeli geniş kapsamlı konuların özelliklerini betimlemeyi hedefleyen araştırmalardır. Bu tür araştırmalar, daha çok "ne, nerede, ne zaman, hangi sıklıkta, hangi düzeyde, nasıl” gibi soruların cevaplandırılmasına olanak tanır. Bu tür araştırmaların amacı genellikle araştırma konusunun mevcut durumunun fotoğrafını çekerek bir betimleme yapmaktır (Büyüköztürk, Çakmak, Akgün, Karadeniz, \& Demirel, 2016). Yapılan bu araştırmada hayat boyu öğrenme alanında Ocak 2007 - Aralık 2017 yılları arasında Web of Science'da yer alan ve SCI-Expanded, SSCI ile A\&HCI atıf indekslerinde yayınlanan makaleleri incelemek amaçlanmıştır.

\section{Verilerin Toplanması ve Analizi}

Bu çalışma tarama modeli çerçevesinde doküman incelemesi tekniği ile gerçekleştirilmiş olup, Ocak 2007 Aralık 2017 yılları arasında yayınlanan ve Web of Science'da SCI-Expanded, SSCI ile A\&HCI atıf indekslerinde yapılan arama sonuçlarında çıkan 297 makale incelenmiştir. Araştırma kapsamında araştırmacılar tarafindan geliştirilen makale inceleme formu kullanılmış olup, incelenen makalelerden elde edilen veriler betimsel yöntemler kullanılarak analiz edilmiştir. Elde edilen bulgular yüzde ve frekans bilgileri verilerek grafik halinde sunulmuştur.

\section{Bulgular}

Bu bölümde, araştırmanın amacı doğrultusunda elde edilen bulgular ve yorumları verilmiştir.

\section{Makalelerin Yayınlandıkları Dergilere Göre Dağılımı}

Araştırmanın amacı doğrultusunda Web of Science'da makale başlıkları içerisinde yapılan "Lifelong Learning" taramasından sonra çıkan sonuçlarda elde edilen 297 makale, toplamda 205 farklı dergide yayınlanmıştır. Bu 205 derginin yayınlanan makale sayısına göre dağılımı Şekil 1'de gösterilmiştir.

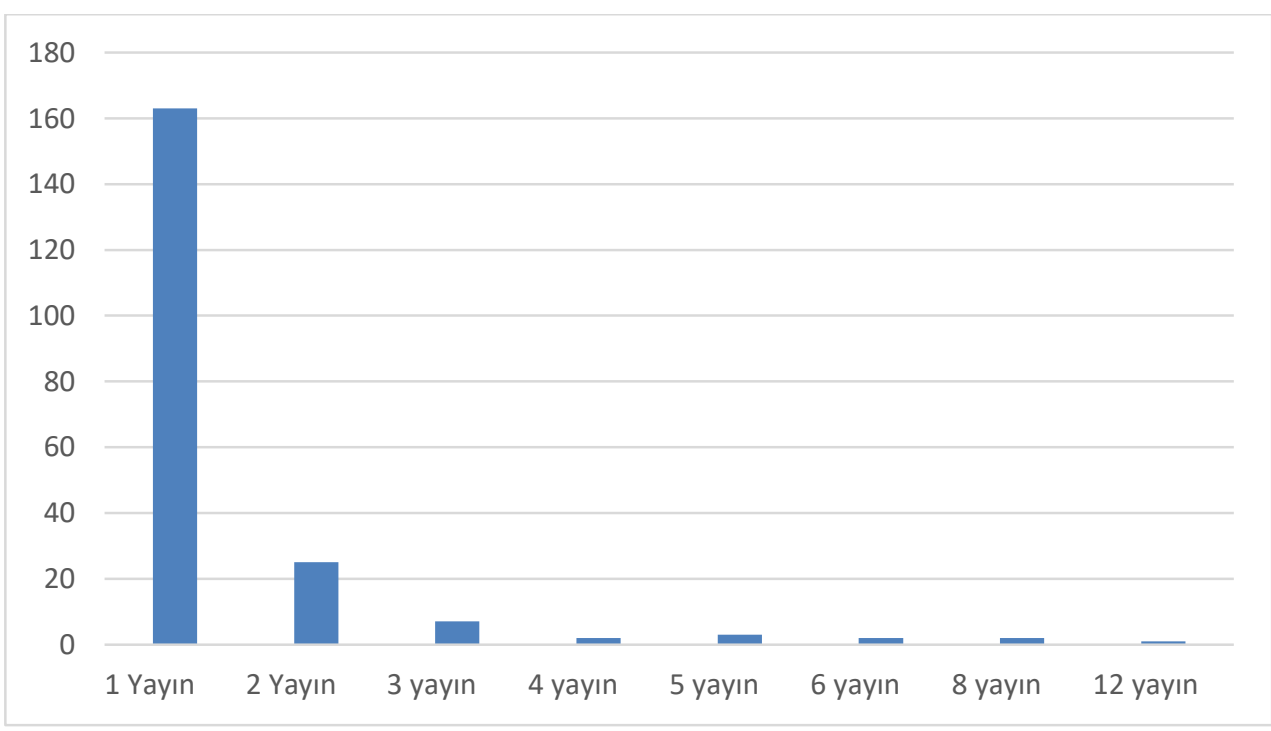

Şekil 1. Yayınlanan makale sayısına göre dergilerin dağılımı 
Yayınlanan makale sayısına göre dergiler incelendiğinde, 1 yayın yapan dergi sayısının 163 (\%79.51) olduğu, 2 yayın yapan dergi sayısının 25 (\%12.20), 3 yayın yapan dergi sayısının 7 (\%3.41), 4 yayın yapan dergi sayısının 2 (\%0.98), 5 yayın yapan dergi sayısının $3(\% 1.46), 6$ ve 8 yayın yapan 2'şer ( $\% 0.98)$ dergi olduğu ve 12 yayın yapan $1(\% 0.49)$ dergi olduğu görülmüştür. Bu verilere göre araştırmanın amacı doğrultusunda Ocak 2007 ile Aralık 2017 arasında hayat boyu öğrenme alanı ile ilgili sadece bir derginin 10'dan fazla yayın yaptığı söylenebilir.

En fazla makale yayınlayan 10 derginin grafiksel dağılımı Şekil 2'de gösterilmektedir. Şekil 2'deki veriler incelendiğinde 297 makale içerisinde, 12 yayın (\%4.04) sayısıyla en fazla yayın yapan derginin "European Journal of Education" olduğu görülmektedir. Bunu sirasıyla "Asia Pacific Education Review" ve "KEDI Journal of Educational Policy" dergileri 8'er yayınla (\%2.69) takip etmektedir. Sirasıyla, 6'şar yayın (\%2.02) yapan "Adult Education Quarterly" ve "Studies in Continuing Education" dergileri, 5'er yayın (\%1.68) yapan "Australian Journal of Adult Learning", "Educational Gerontology" ve "International Journal of Engineering Education" dergileri ve 4'er yayın (\%1.35) yapan "Journal of Education Policy" ve "Academic Medicine" dergileri takip etmektedir. Bu bulgulara göre en fazla yayın yapan ilk 10 dergi içerisinde eğitim alanıyla ilgili dergilerin sayısının diğer alanlara göre daha fazla olduğu söylenebilir.

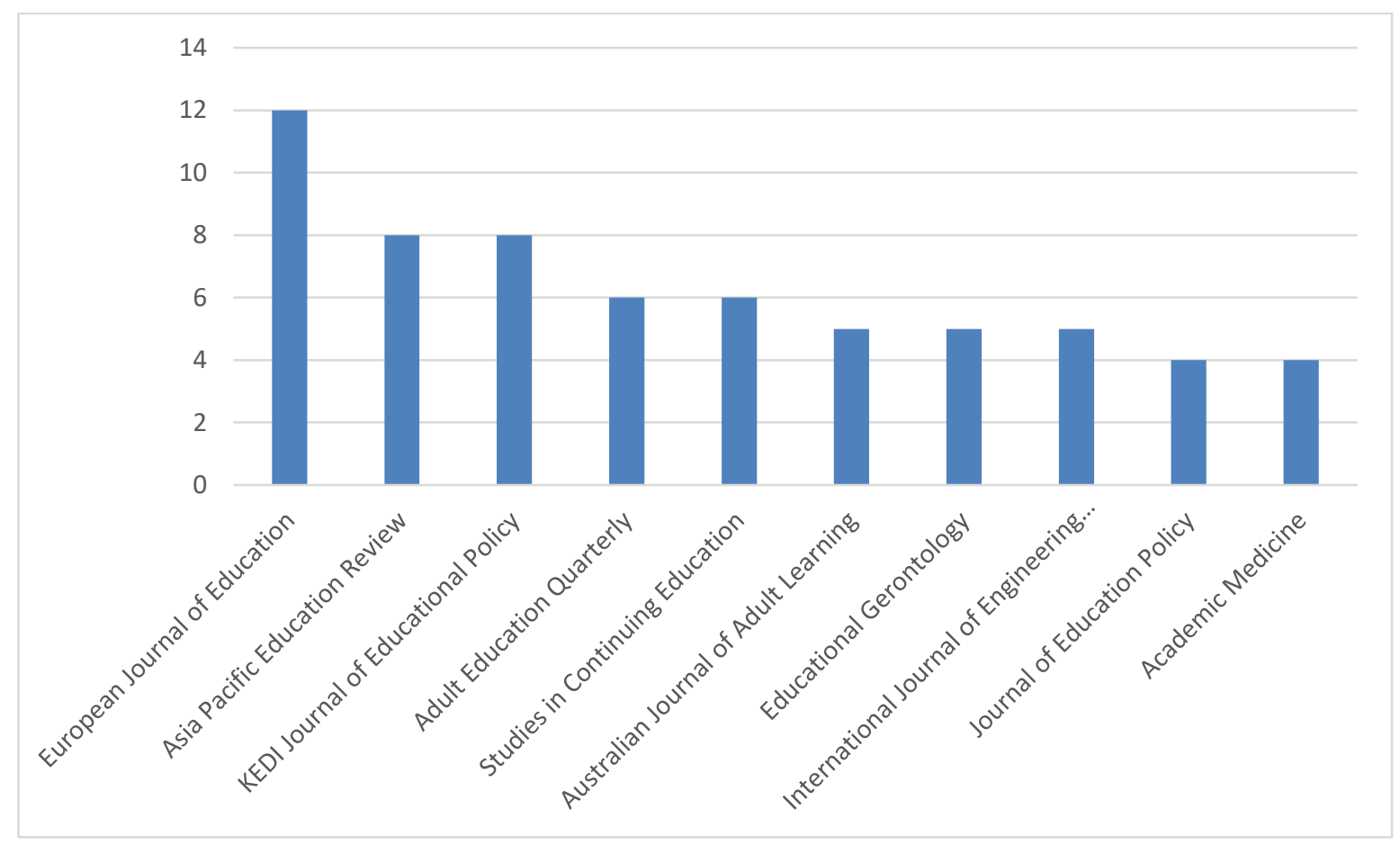

Şekil 2. En fazla makale yayınlayan ilk 10 dergi

Araştırma kapsamında yapılan arama sonuçlarında ulaşılan 205 dergi içerisinde Türkiye'de yayın yapan dergilerin sayıs 5'tir (\%2.43). Bu dergiler 3'er yayın (\%1.01) yapan "Eğitim ve Bilim" ve "Hacettepe Üniversitesi Eğitim Fakültesi Dergisi”, 1'er yayın (0.34) yapan "Amme İdaresi Dergisi", "Bilig" ve "TOJET: The Turkish Online Journal of Educational Technology" dergileridir. Türkiye'de yayın yapan dergilerin grafiksel gösterimi Şekil 3'te gösterilmiştir. 


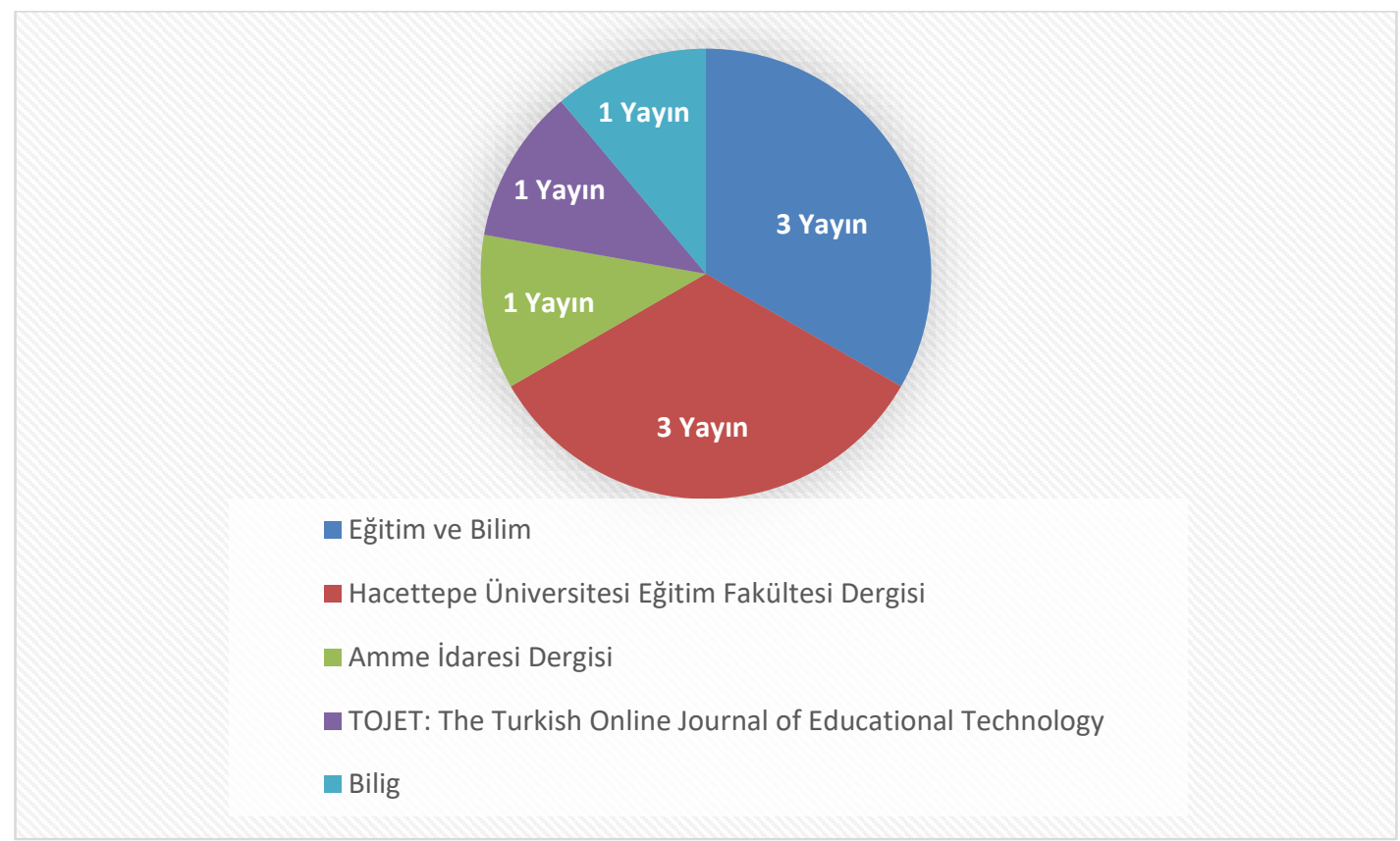

Şekil 3. Türkiye'de yayınlanan dergilerin dağılımı

\section{Makalelerin Yazıldıkları Dillere Göre Dağılımı}

Araştırma kapsamında incelenen makaleler, yazıldıkları dillere göre incelendiğinde "İngilizce" dilinin diğer dillere göre baskın olduğu görülmektedir. Makalelerin yazıldıkları dillere göre dağılımı Şekil 4 'te verilmiş̧tir.

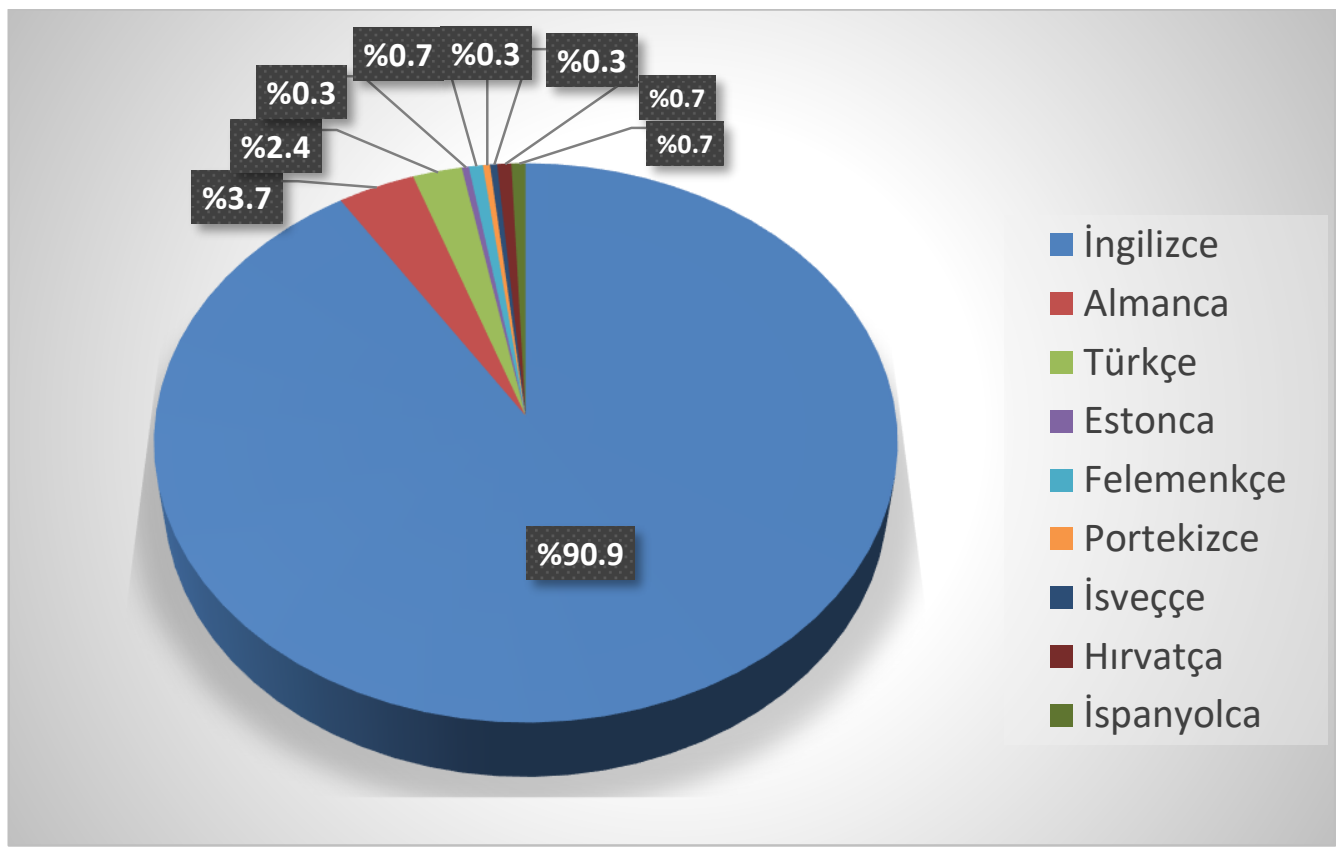

Şekil 4. Makalelerin yazıldıkları dillere göre dağılımı 
Makalelerin yazıldıkları dillere göre dağılımı incelendiğinde, "İngilizce" dilinde yazılan makale sayısının 270 (\%90.9) olduğu, "Almanca" yazılan makale sayısının 11 (\%3.7) olduğu, "Türkçe" yazılan makale sayısının 7 (\%2.4) olduğu, "Felemenkçe", "Hırvatça" ve "İspanyolca" 2 makale (\%0.7) yazıldığı ve "Estonca", "Portekizce" ve "İsveççe" 1 makale (\%0.3) yazıldığ 1 görülmüştür. Buna göre ISI Web of Science'da araştırmanın amacı doğrultusunda yapılan arama sonuçlarında çıkan makalelerin en fazla "İngilizce" dilinde yazıldığı anlaşılmaktadır. Bu noktada "İngilizce" dilinin bütün dünyada kullanılan ortak dil olmasının etkisinin büyük olduğu söylenebilir. "Türkçe" dilinde yazılan makale sayısının "İngilizce" ve "Almanca" dillerinden sonra gelmesi, ülkemizde bu alana duyulan ilginin göstergesi olarak yorumlanabilir.

\section{Makalelerde Kullanılan Yöntemler}

Araştırma kapsamında yapılan arama sonuçlarında ulaşılan makaleler, kullandıkları yöntemlere göre incelendiğinde nitel yöntemlerin $(\mathrm{n}=185, \% 62.3)$ tüm araştırmaların yarısından fazlasında tercih edildiği görülmektedir. Nitel araştırmaları, nicel $(n=88, \% 29.6)$ ve karma yöntem $(n=24, \% 8.1)$ izlemektedir. Makalelerin kullandıkları yöntemlere göre dağılımı Şekil 5'te verilmiştir.

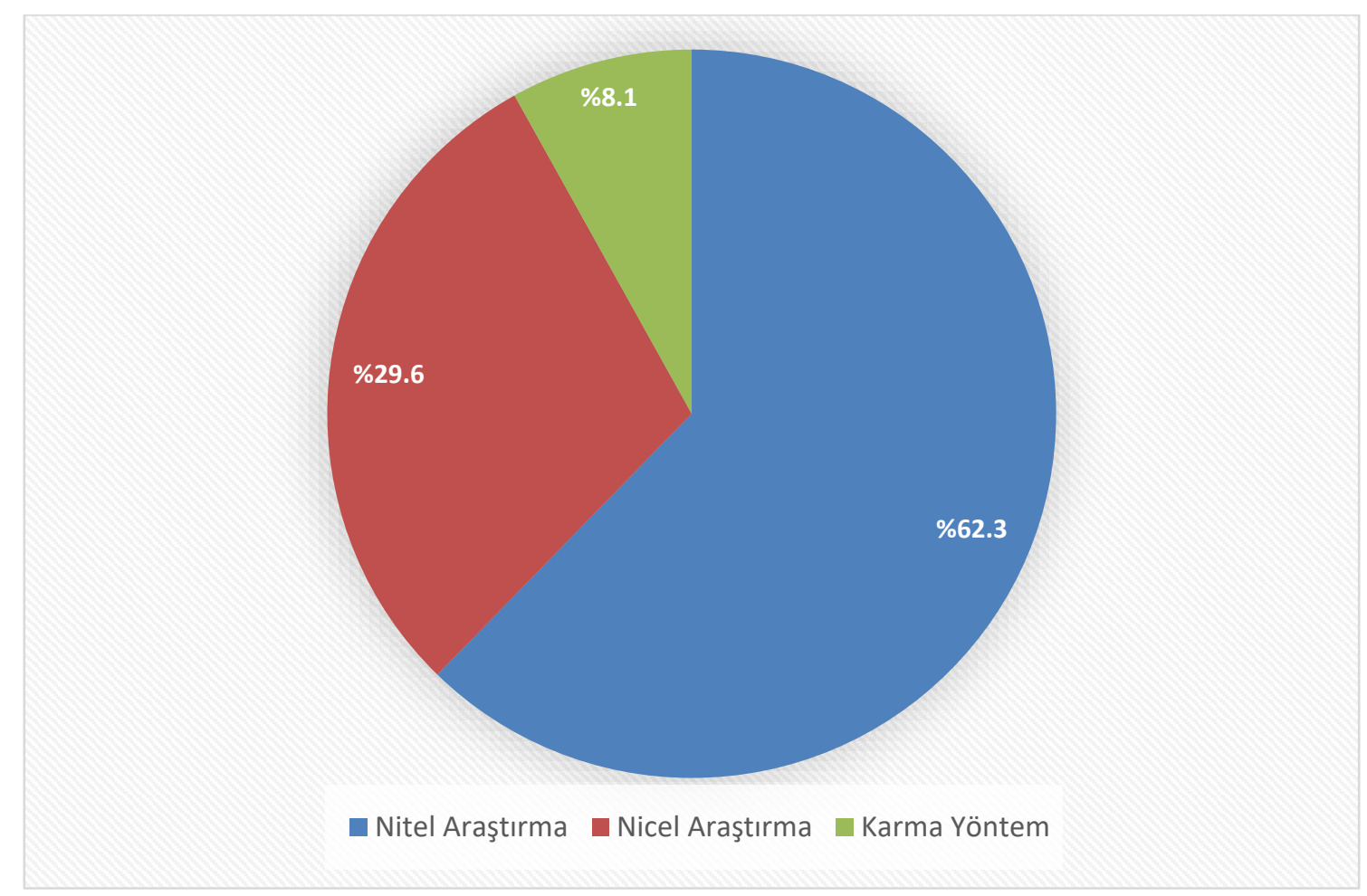

\section{Şekil 5. Makalelerin Kullandıkları Yönteme Göre Dağılımı}

Türkiye'de yayın yapan dergilerde yayınlanan makalelerin, kullandıkları yöntemler incelendiğinde toplam 9 makalenin 4'ünün (\%44.4) nitel yöntem, 4'ünün (\%44.4) nicel yöntem ve 1 tanesinin (\%11.1) karma yöntem kullandığı görülmüştür. Türkiye'de yayın yapan dergilerde yayınlanan makalelerin kullandıkları yöntemlere göre dağılımını gösteren grafik Şekil 6'da verilmiştir. 


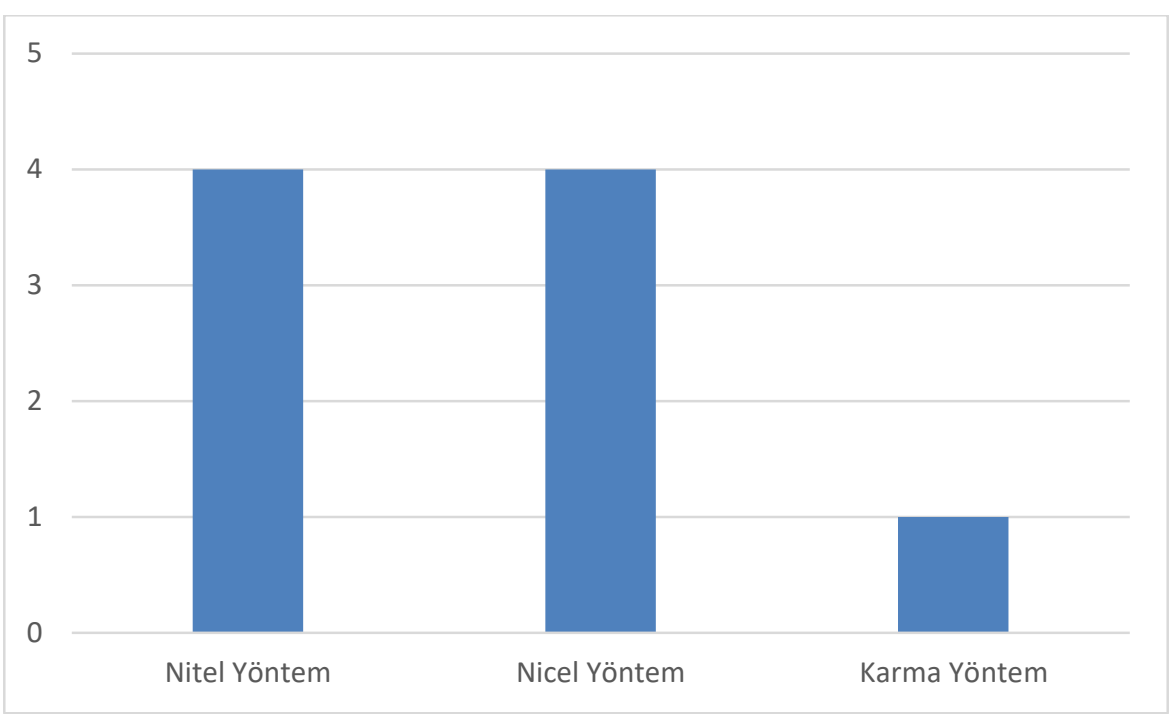

Şekil 6. Türkiye'de yayın yapan dergilerde yayınlanan makalelerin kullandıkları yönteme göre dağılımı

\section{Makalelerde Belirtilen Veri Analiz Yöntemlerinin Dağılımı}

Araştırma için incelenen makalelerin veri analiz yöntemleri incelendiğinde 198 çalıșmada (\%66.66) nitel veri analiz yöntemlerine rastlanırken, 152 çalışmada (\%51.17) nicel veri analiz yöntemlerine rastlanmıştır. Bütün makalelerin içerisinde sadece nitel veri analizi kullanılan 135 çalışma $(\% 45.45)$ bulunurken, sadece nicel veri analizi kullanılan 89 çalışma (\%29.97) bulunmaktadır. 63 makalede de (\%21.21) her iki veri analiz yöntemi kullanılmıștır. Araștırma kapsamında incelenen makalelerin içerisinde 10 çalıșmada (\%3.37) herhangi bir veri analiz yöntemi belirtilmemiştir. Makalelerde belirtilen veri analiz yöntemlerinin dağılımını gösteren grafik, Şekil 7'de verilmiştir.

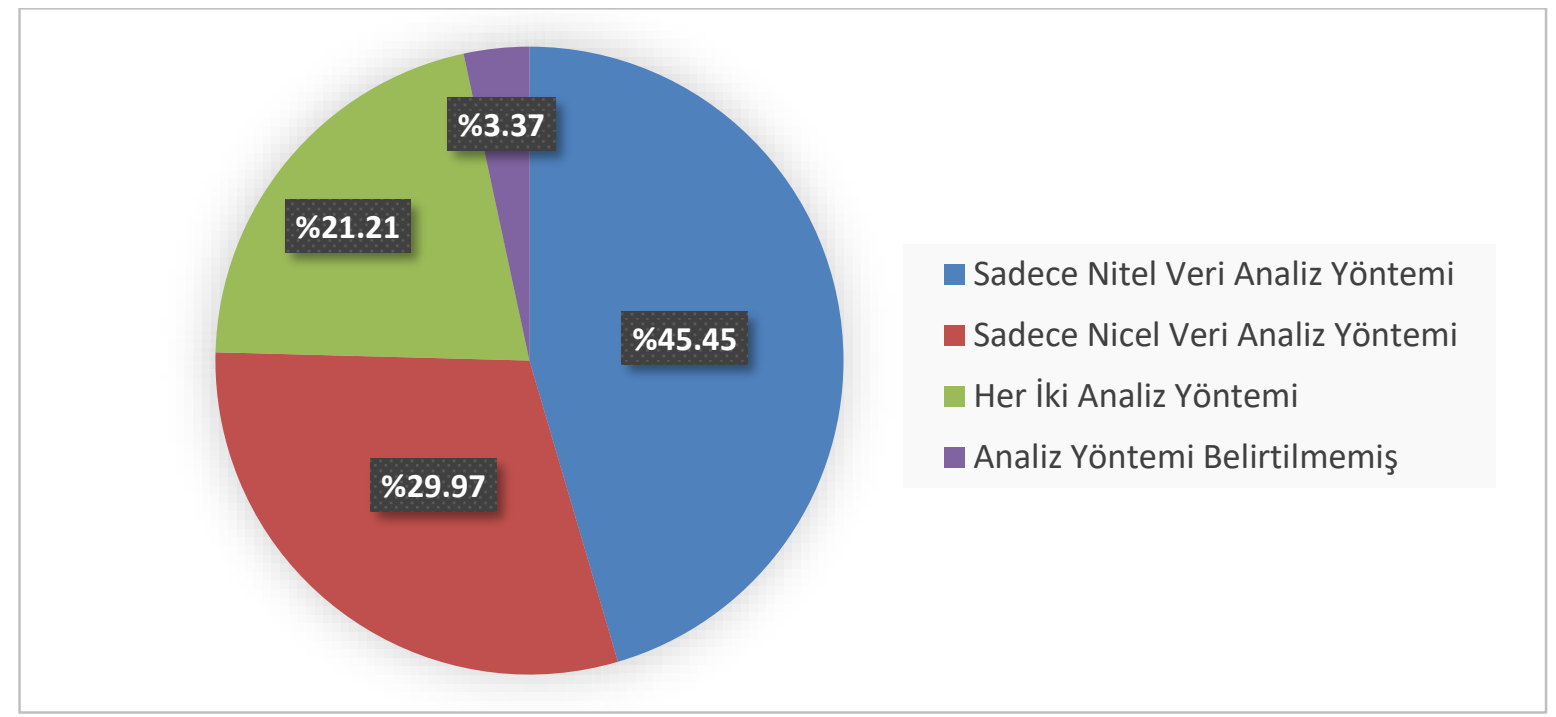

Şekil 7. Makalelerde belirtilen veri analiz yöntemleri

Nitel veri analiz yöntemleri kullanılan 198 makale (\%66.66) kendi içerisinde incelendiğinde, betimsel analiz yönteminin diğer nitel veri analiz yöntemlerine göre daha fazla tercih edildiği görülmektedir ( $\mathrm{n}=102, \% 51.52$ ). İçerik analizi yöntemini kullanan 83 çalışma (\%41.92) bulunmaktadır. 13 makalede de (\%6.56) diğer nitel veri 
analiz yöntemleri kullanılmıştır. Şekil 8'deki grafikte makalelerde kullanılan nitel veri analiz yöntemlerinin dağılımını gösterilmişsir.

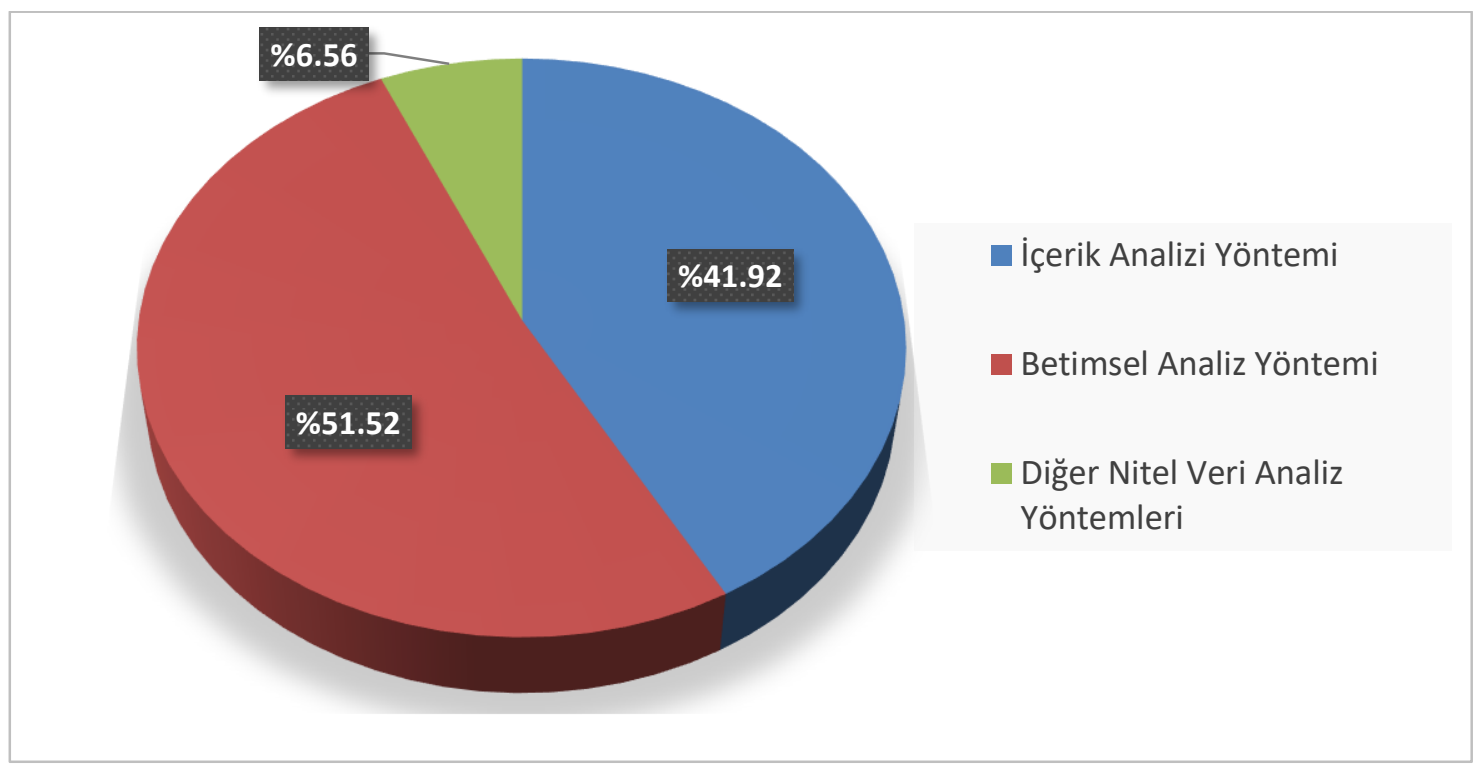

Şekil 8. Makalelerde kullanılan nitel veri analiz yöntemlerinin dağılımı

$\mathrm{Bu}$ çalışma kapsamında incelenen makalelerde nicel veri analiz yöntemleri kullanılan 152 çalışma (\%51.17) kendi aralarında incelendiğinde, sadece betimsel istatistikleri kullanan çalışmaların sadece kestirimsel istatistik kullanan çalışmalara göre daha fazla kullanıldığı bulunmuştur $(\mathrm{n}=67$; \%44.08). 36 makalede (\%23.68) sadece kestirimsel istatistikler kullanılırken her iki istatistik türünü kullanan 49 çalıșma (\%32.24) olduğu görülmüștür. Nicel veri analiz yöntemlerinin kendi aralarındaki dağılımını gösteren grafik Şekil 9'da gösterilmiştir.

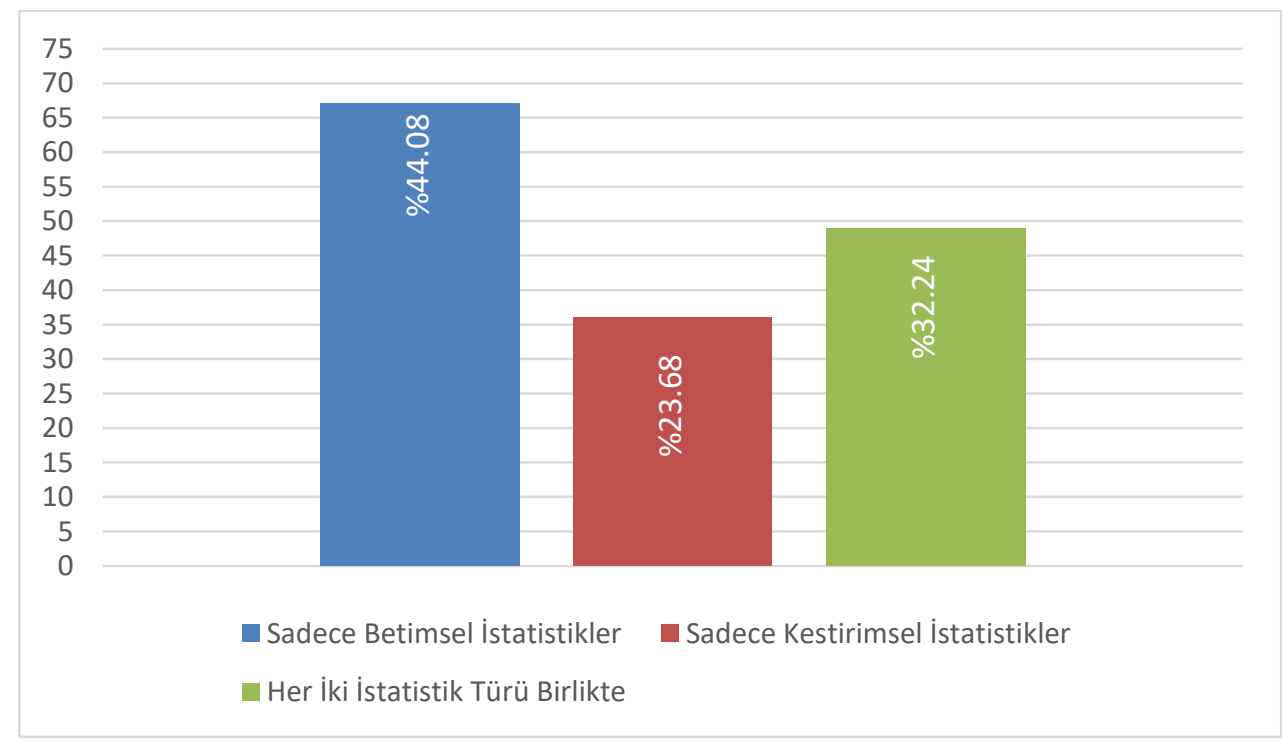

Şekil 9. Makalelerde kullanılan nicel veri analiz yöntemlerinin dağılımı

Nicel veri analiz yöntemi kullanılan 152 makalenin (\%51.17) içerisinde 112 makalede (\%73.68) betimsel istatistikler kullanılmıştır. Bu çalışmalar kendi içerisinde incelendiğinde yalnızca frekans/yüzde istatistikleri 348 
verilen 32 çalışma (\%28.57), sadece ortalama/standart sapma istatistiği kullanılan 2 çalışma (1.79), sadece grafikle gösterim yapan 43 çalışma (\%38.39) olduğu görülmüştür. Hem frekans/yüzde istatistiği hem de ortalama/standart sapma istatistiği kullanılan araştırma sayısı 7 (\%6.25) iken hem frekans/yüzde istatistiği hem de grafikle gösterim yapan araştırma sayısı 25'tir (\%22.32). Ortalama/standart sapma istatistiği ile grafikle gösterim birlikte hiçbir çalışmada yer almazken her üç betimsel istatistiğin birlikte kullanıldığı 3 (\%2.68) çalışma bulunmaktadır. Makalelerde kullanılan betimsel istatistiklerin grafiksel olarak dağılımı Şekil 10'da yapılmıştır.

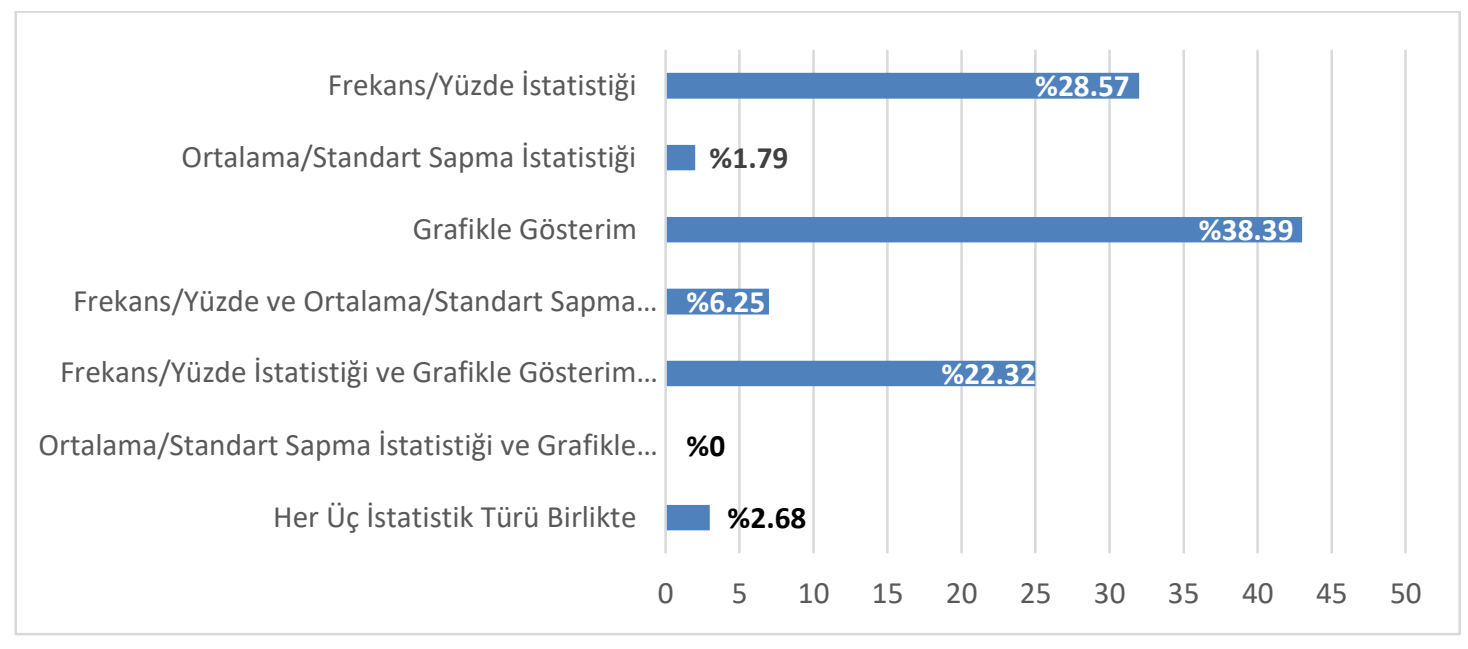

Şekil 10. Makalelerde kullanılan betimsel istatistiklerin dağılımı

Nicel veri analiz yöntemi kullanılan 152 makalenin (\%51.17) içerisinde 85 makalede (\%55.92) kestirimsel istatistikler kullanılmıştır. Bu istatistikler kendi içinde incelendiğinde 19 defa (\%22.35) korelasyon analizi, 23 defa (\%27.06) t-testi, 20 defa (\%23.53) Anova/Ancova analizi, 4 defa (\%4.71) Manova/Mancova analizi, 17 defa (\%20) faktör analizi, 28 defa (\%32.94) regresyon analizi, 9 defa (\%10.59) parametrik olmayan analizler ve 31 defa (\%36.47) diğer kestirimsel istatistikler kullanıldığ1 görülmüştür. Makalelerde kullanılan kestirimsel istatistiklerin dağılımını gösteren grafik Şekil 11'de gösterilmiştir.

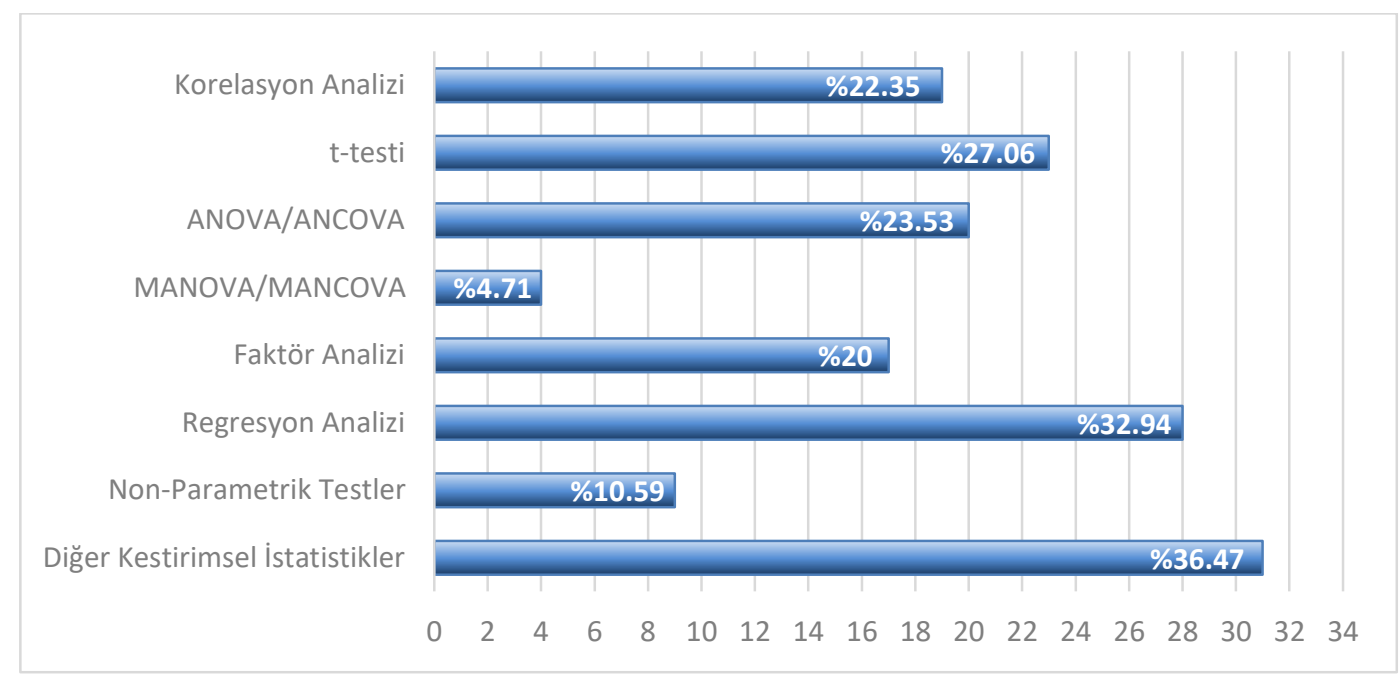

Şekil 11. Makalelerde kullanılan kestirimsel istatistiklerin dağılımı

\section{Makalelerde Belirtilen Veri Toplama Araçlarının Dağılımları}


$\mathrm{Bu}$ çalışma kapsamında incelenen makaleler veri toplama araçları bakımından incelendiğinde en az bir tane veri toplama aracı kullanan 269 çalışma (\%90.57) olduğu görülmüştür. Hiçbir veri toplanmadan hazırlanan çalışma sayısı 28'dir (\%9.43). Araştırmalar yapılırken kullanılan veri toplama araçları incelendiğinde gözlem yapılan çalışma sayısı 9 (\%3.03), görüşme yapılan çalışma sayısı 40 (\%13.47), ölçek kullanılarak yapılan araştırma sayısı 30 (\%10.10), anket kullanılarak yapılan araştırma sayısı 68 (\%22.90), dökümanlardan yararlanılan araştırma sayısı 101 (\%34.01) ve bunlardan farklı veri toplama aracı kullanan veya kendi veri toplama yöntemini geliştiren çalışma sayısı 91 (\%30.64)'tür. Araştırma kapsamında incelenen makalelerin kullandıkları veri toplama araçlarına göre dağılımını gösteren grafik Şekil 12'de verilmiştir.

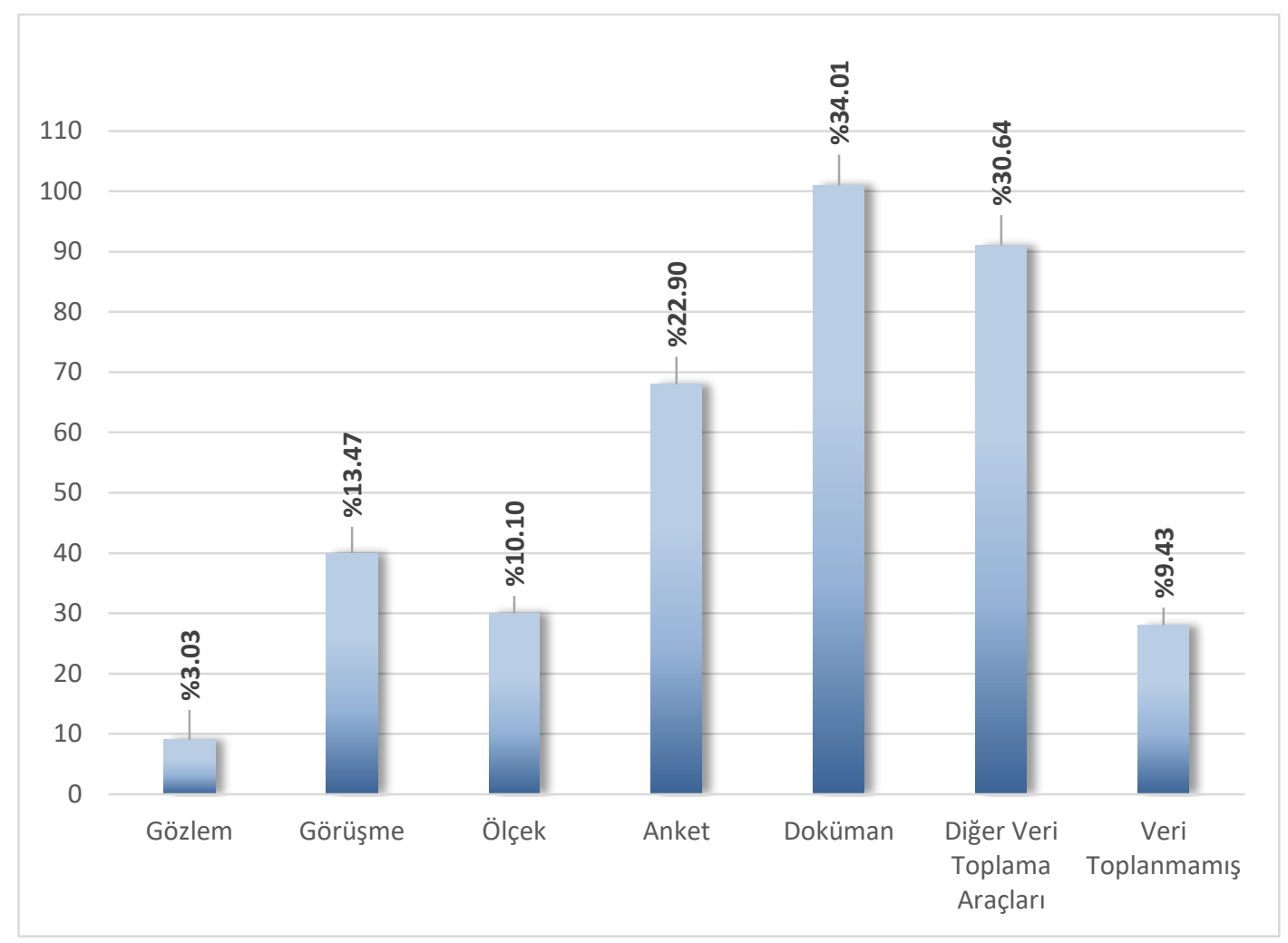

Şekil 12. Makalelerde kullanılan veri toplama araçlarının dağılımı

\section{Makalelerde Belirtilen Katılımcıların Makale Sayısına Göre Dă̆ılımları}

Araştırma kapsamında incelenen makalelerde katılımcıları belirtilen makale sayısı 101'dir (\%34). Bu 101 makale içerisinde belirtilen katılımcıların makale sayısına göre dağılımı Şekil 13 'te gösterilmiştir. 


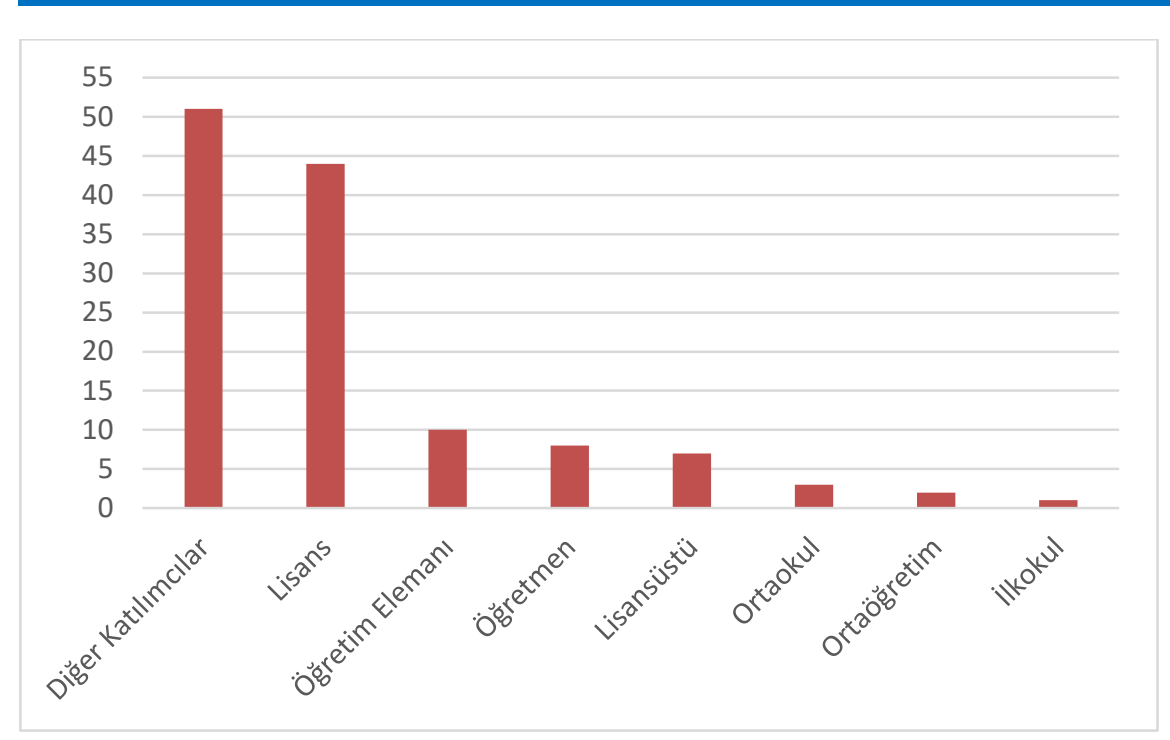

Şekil 13. Makalelerde belirtilen katılımcıların makale sayısına göre dağılımları

Şekil 13'deki verilere göre araştırmalarda yer alan katılımcıların belirtildiği makalelerin 51'i (\%50.5) diğer katılımcılar kategorisinde bulunan bireylerle çalışmışlardır. Bu kategoride, istihdam edilmiş veya istihdam edilmemiş bireyler, profesyonel kaptanlar, çeşitli türde gemi kullanım lisansına sahip kişiler, doktorlar, hemşireler, eczacılar, yetişkinler, hükümet ve yarı-resmi kuruluşların temsilcileri, politika yapıcılar, yöneticiler, spor antrenörleri, psikiyatrlar, görme engelli müzisyenler, şirketler, okul ve ofis çalışanları, veterinerler, diş hekimleri gibi değişik meslek gruplarından veya farklı görevlerden bireyler bulunmaktadır. Diğer katılımcılar kategorisinden sonra 44 makale (\%43.6) ile lisans öğrenimi gören bireyler gelmektedir. Daha sonra sırasıyla öğretim elemanları 10 makalede (\%9.9), öğretmenler 8 makalede (\%7.9), lisansüstü eğitime devam edenler 7 makalede (\%6.9), ortaokul öğrencileri 3 makalede (\%3), ortaöğretime devam eden öğrenciler 2 makalede (\%2) ve ilkokul öğrencileri 1 makalede (\%1) yer almışlardır. Bu bulgular ışı̆̆ında hayat boyu öğrenme alanı ile ilgili yapılan çalışmaların daha çok çalışan bireyler veya çalışma hayatına hazırlanan bireyler üzerinde gerçekleştirildiği, özellikle üniversite öncesi eğitim alan bireylerin bu alandaki çalışmalarda oldukça az görüldüğü söylenebilir.

\section{Makalelerde Belirtilen Katılımcıların Yaşa Göre Dağılımları}

Araştırma kapsamında yapılan arama sonuçlarında ulaşılan makalelerde, çalışmalara katılan katılımcıların yaş durumlarının belirtildiği 49 makale (\%16.49) olduğu görülmüştür. Bu 49 çalışmada belirtilen yaş grupları "0-5 yaş", “6-8 yaş”, "9-14 yaş”, “15-18 yaş”, "19-30 yaş”, “31-40 yaş”, "41-50 yaş”, "51-60 yaş" ve "61 ve üzeri” olmak üzere 9 yaş grubuna ayrılmış ve toplam 146 grup olduğu bulunmuştur. Bu 146 grup içerisinde "0-5 yaş" grubuyla çalışılan hiçbir makale bulunmamaktadır (n=0, \%0). "6-8 yaş" aralığında 2 grup (\%1.37), "9-14 yaş", aralığında 3 grup (\%2.05), "15-18 yaş” aralığında 8 grup (\%5.48), “19-30 yaş” aralığında 31 grup (\%21.23), "3140 yaş” aralığında 32 grup (\%21.92), “41-50 yaş” aralığında 27 grup (\%18.49), "51-60 yaş” aralığında 25 grup (\%17.12), "61 ve üzeri” yaş grubunda 18 grup (\%12.33) olduğu görülmüştür. Ulaş1lan bu sonuçlara göre çalışmalarda 31 yaş ve üzerinde 102 grup (\%69.86) olduğu ve 30 yaş ve altında 44 grup (\%30.14) bulunduğu görülmektedir. Makalelerde belirtilen katılımcıların yaşa göre dağılımlarını gösteren grafik Şekil 14'te gösterilmiştir. 


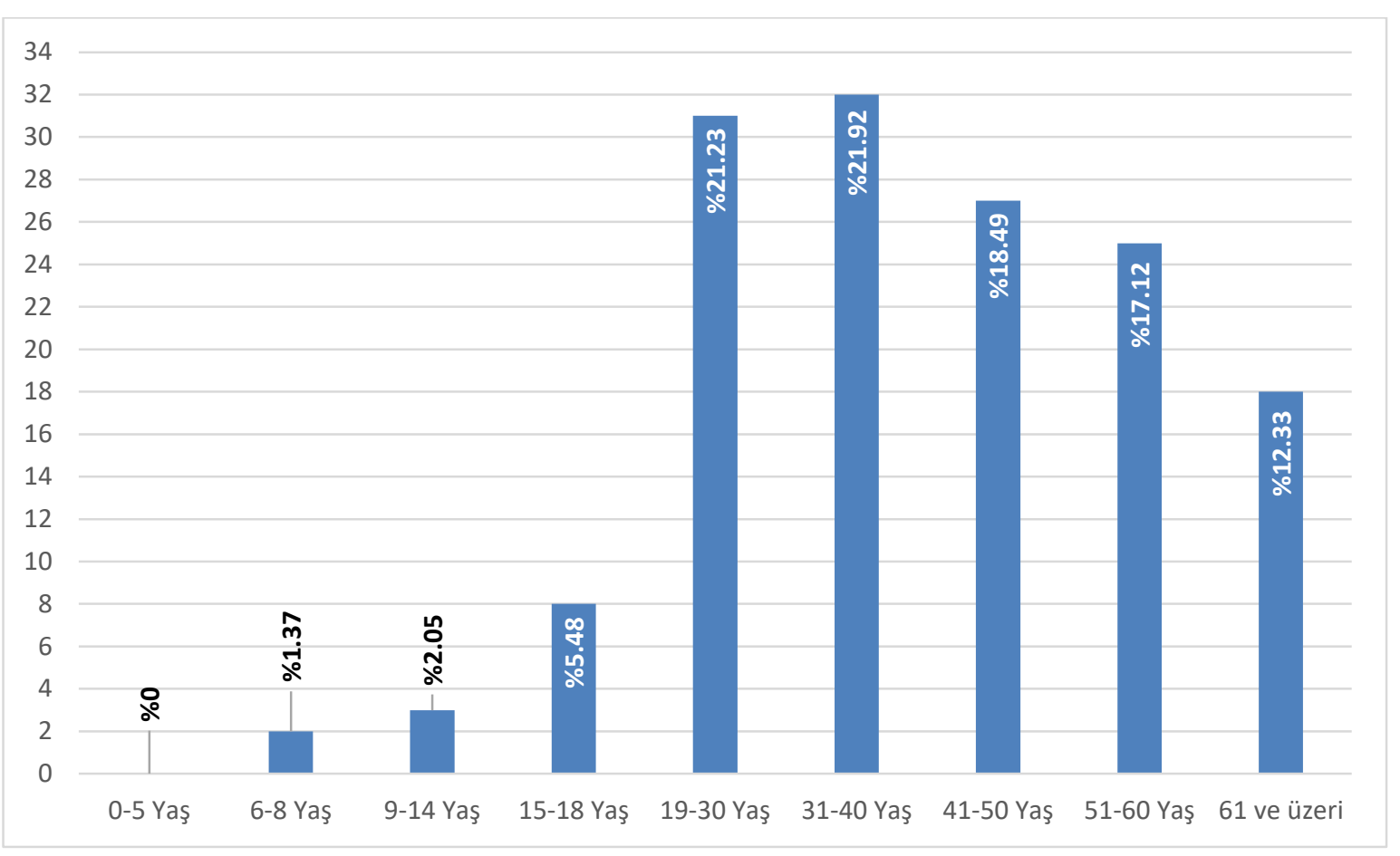

Şekil 14. Makalelerde belirtilen katılımcıların yaşa göre dağılımları

\section{Makalelerde Belirtilen Örneklem Boyutlarının Dağılımı}

Bu çalışma kapsamında incelenen 297 makalenin 127 tanesinde (\%49.76) örneklem boyutları belirtilmiştir. Bu örneklem boyutları "1-10 aras1 katılımc1", "11-30 aras1 katılımc1", "31-100 aras1 kat1lımc1", "101-300 aras1 katılımcı”, “301-1000 arası katılımcı” ve “1000’den fazla katılımcı” olmak üzere 6 grup altında incelenmiştir. 110 arası katılımcı ile çalışılan 10 araştırma (\%7.87), 11-30 arası katılımcıyla çalışılan 21 araştırma (\%16.54), 31100 arası katılımcıyla çalışılan 18 araştırma (\%14.17), 101-300 arası katılımcıyla çalışılan 30 araştırma (\%23.62), 301-1000 arası katılımcıyla çalışılan 23 araştırma (\%18.11) ve 1000'den fazla katılımcıyla çalışılan 25 araştırma (\%16.69) olduğu saptanmıştır. 78 çalışma 101 kişi ve üzerinde katılımcıyla gerçekleştirilmiştir $(\% 61.42)$. Örneklem boyutlarının dağılımını gösteren grafik Şekil 15'de verilmiştir.

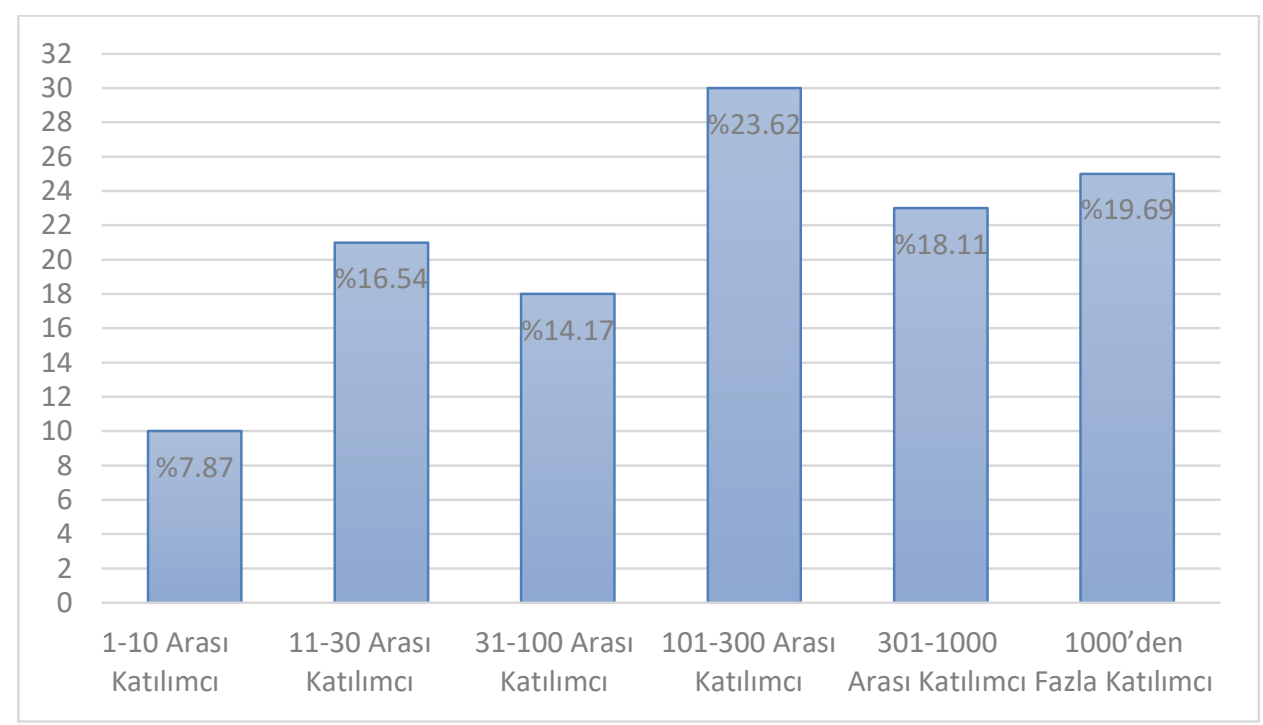

Şekil 15. Makalelerde belirtilen örneklem boyutlarının dağılımları 352 


\section{Makalelerde Belirtilen Anahtar Sözcüklerin Dağılımı}

Çalışma kapsamında incelenen 297 makalenin 82 tanesinde (\%27.61) anahtar kelime belirtilmemiştir. Anahtar kelime belirtilen 215 makale (\%72.39) incelendiğinde toplam 774 farklı kelimenin toplam 1230 defa kullanıldı̆̆ bulunmuştur. Bu kelimeler içerisinde 1 kelime 120 defa (\%9.76), 1 kelime 12 defa (\%0.98), 1 kelime 11 defa (\%0.89), 1 kelime 10 defa (\%0.81), 2 kelime 9 defa (\%0.73), 1 kelime 8 defa (\%0.65), 5 kelime 6 defa (\%0.49), 2 kelime 5 defa (\%0.41), 8 kelime 4 defa (\%0.33), 15 kelime 3 defa (\%0.24), 49 kelime 2 defa (\%0.16) ve 688 kelime 1 defa (\%0.08) kullanılmıştır. Makalelerde belirtilen anahtar sözcüklerin sayısal olarak dağılımını gösteren grafik Şekil 16'da verilmiştir.

\section{Tekrarlanma Sayısı}

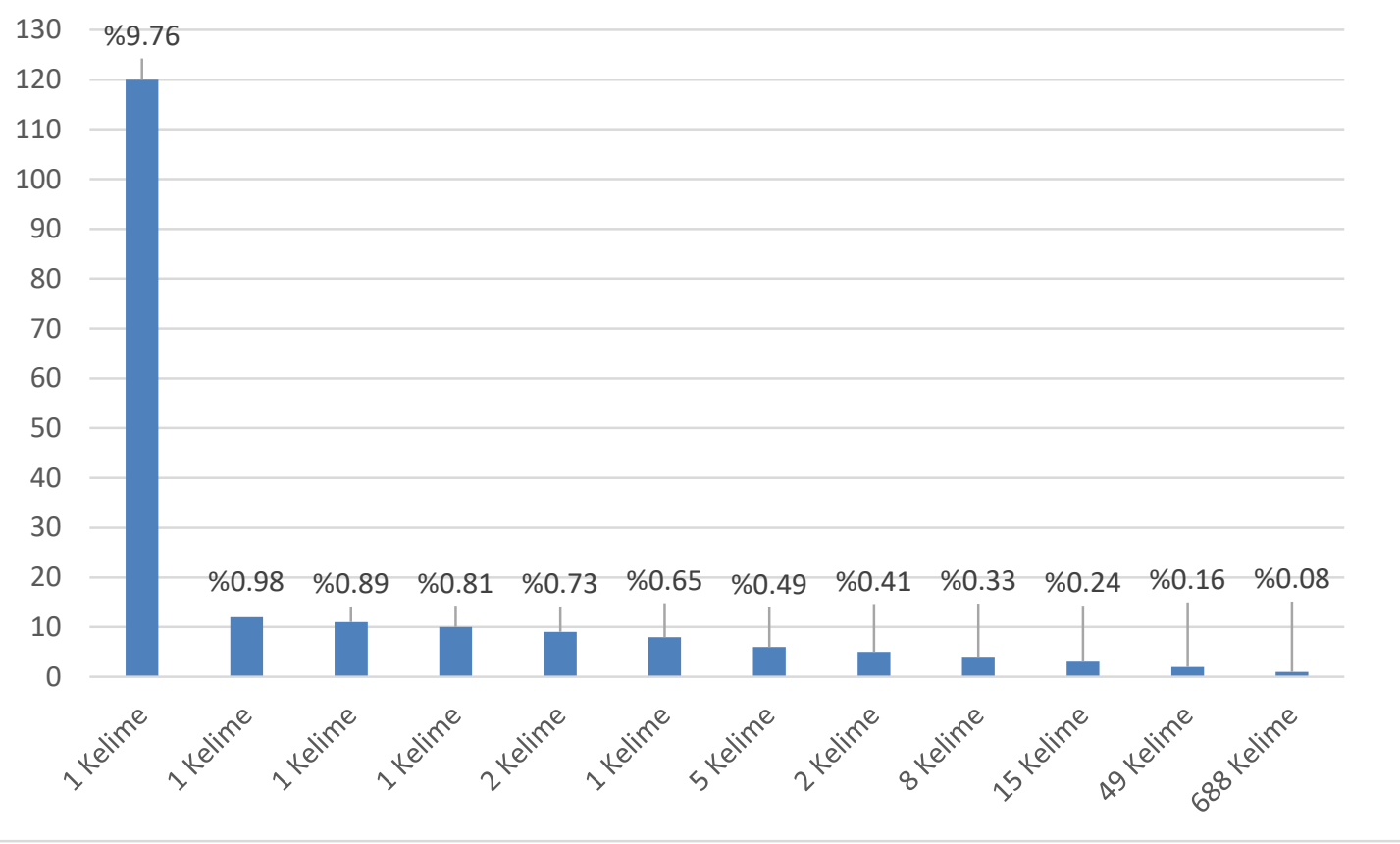

Şekil 16. Makalelerde belirtilen anahtar sözcüklerin sayısal olarak dağılmı

Kullanılan anahtar kelimeler içerisinde en çok kullanılan kelime "Lifelong Learning" kelimesidir ( $\mathrm{n}=120$, \%9.76). Bunun dışında en çok kullanılan ilk 5 kelime sırasıyla "Adult Education" (n=12, \%0.98), "Life-long Learning" ( $\mathrm{n}=11, \% 0.89)$, "Education" ( $\mathrm{n}=10, \% 0.81)$, "Learning" ve "Continuing Education" kelimeleri ( $\mathrm{n}=9$, $\% 0.73$ ) kelimeleridir. Makalelerde en çok kullanılan ilk 5 anahtar kelimenin grafiği Şekil 17'de verilmiştir. 


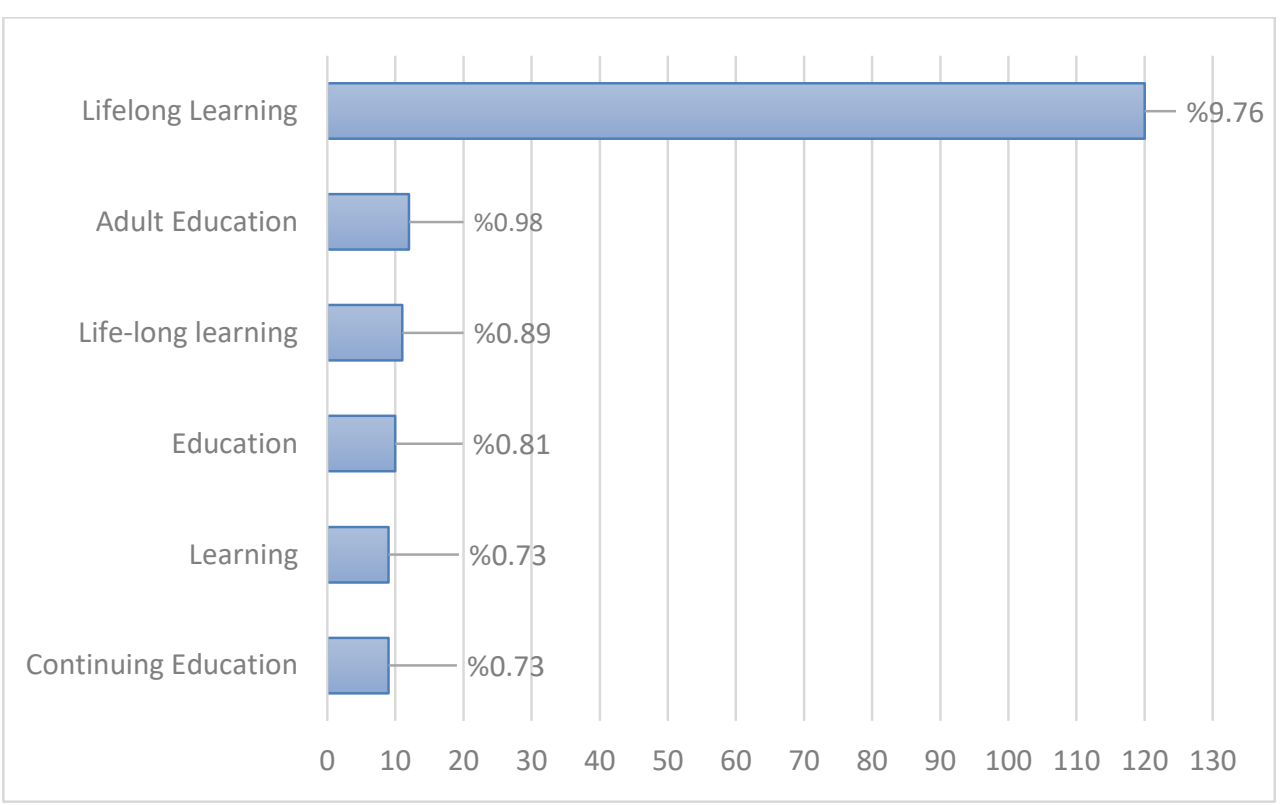

Şekil 17. Makalelerde en çok kullanılan ilk 5 anahtar kelime

\section{Tartışma ve Sonuc}

Öğrenme, biz insanların günlük hayatta yaptığı herhangi bir şey değil; üretken insanlar olarak günlük hayatımızda yaptığımız her şeyin merkezidir. Öğrenmeyi geliştirmek, insanların, politika yapıcıların ve hükümetlerin yatırım yapması gereken en önemli faaliyetlerden biridir (Wagner, 2015). İşte bu yüzden hayat boyu öğrenme alanı son yıllarda oldukça popüler olan, araştırmacıların yoğun ilgi gösterdiği çalışma alanlarından biridir (Kabataş \& Karaoğlan Yılmaz, 2018). Bunun en önemli sebeplerinden birisi günümüz toplumunun karmaşık yapısının, dinamik ve sürekli değişen bilgiyle, internet, multimedya ve eğitim teknolojisinin kitlesel kullanımıyla, daha esnek bir işgücü talep eden ve sürekli değişen işgücü piyasasıyla daha da karmaşık hale gelmesidir. Toplumlar bu karmaşık yapının üstesinden gelebilmek için, hayat boyu öğrenme alanına yönelmekte ve bu alanda daha yoğun çalışmalarda bulunmaktadırlar (Dochy, Segers, Van den Bossche, \& Gijbels, 2003). İnsanların içinde yaşadığımız dünyaya ayak uydurması için hayat boyu öğrenme becerilerini geliştirmeleri, bunun farkında olmaları çok önemlidir. Hayat boyu öğrenme öncelikle insan yaşamının sürekli güncellenen gereklilikleri ve her geçen gün artan yeni bilgilerin ortaya çıkardığı farkı kapamaya yöneliktir. Günlük yaşantıda karşımıza çıkan yeni teknolojik gelişmeler, yeni oluşumlar ve yapılanmalar bireyden sürekli olarak kendini yenilemesi ve mevcut bilgi birikimini artırmasını beklemektedir. Tüm bunlar bireyin sadece okuldan aldığı eğitimle hayatını sürdürmesine izin vermemektedir (Topakkaya, 2013). Ekonomiye dayalı olan günümüz iş dünyasında var olabilmek, günlük hayattaki işleri yapabilmek, sürekli gelişen teknoloji dünyasına ayak uydurabilmek gibi eylemleri gerçekleştirmek bireylerin hayat boyu öğrenme becerilerine bağlıdır. Bu becerilerin kazandırılabilmesi ve geliştirilebilmesi için eğitim sistemlerinin, metotlarının veya materyallerinin yenilenmesi, geliştirilmesi bu alanda yapılacak olan çalışmaların niteliğine oldukça bağlıdır (Sezer, Karaoğlan Yılmaz, \& Yılmaz, 2017). Bu kapsamda araştırmanın amacı doğrultusunda Ocak 2007 ve Aralık 2017 yılları arasında Web of Science'da SCI-Expanded, SSCI ile A\&HCI atıf indekslerinde yapılan arama sonuçlarında çıkan makaleler yayınlandıkları dergiler, yazıldıkları diller, kullanılan yöntemler ve katılımcılar bağlamında incelenmiştir.

Çalışmadan elde edilen bulgulara göre hayat boyu öğrenme alanıyla ilgili yapılan çalışmaların birçok farklı dergide yayınlandığı görülmüştür. Araştırma kapsamında incelenen 297 makalenin 205 farklı dergide yayınlanması akademik dergi çeşitliliğinin çok olduğunun bir göstergesidir. Aynı zamanda akademik dergi çeşitliliğinin çok olması, akademik çalışmaların hayat boyu öğrenmeye olan ilgisinin yoğun olduğunu göstermektedir. Ancak, bu kadar çok akademik dergi çeşitliliğinin içerisinde çok az sayıda Türkiye'de yayın yapan akademik dergi vardır ( $\mathrm{n}=5$ ). Bunun sebebi olarak, Türkiye'deki üniversitelerde hayat boyu öğrenme ile ilgili 
bölümlerin az olması, farklı meslek grupları ile ilgili bölümlerin verdiği derslerde içerik olarak yeni yeni yer alması, bu alandaki lisansüstü mezunların sayısının azlığı gösterilebilir. Yüksek Öğretim Kurulu özellikle 2005 yılından sonra bu konuya ilgi göstermeye başlamış ve son yıllarda giderek artan bir şekilde konuyu akademi çevrelerinin gündemine getirmeye çalışmıştır (Topakkaya, 2013). Hayat boyu öğrenme kavramı Türkiye için yeni bir kavram olmamakla birlikte yaygın da değildir ve günümüzde mevcut şartların oldukça uzağında yürütülmektedir (Taşçı ve diğerleri, 2015). Avrupa'nın bu konuya 1900'lü yıllardan itibaren artan ilgisi göz önüne alındığında, Türkiye'nin bu konuda biraz geriden geldiğini söylemek mümkündür.

Makalelerin yazıldıkları dillere göre dağılımına göre makalelerin tamamına yakını "İngilizce" dilinde yazılmıştır (\%90.9). Bunun sebebi olarak dünyanın her yerinde, diğer dillere oranla, en çok tercih edilen ortak dilin İngilizce olması gösterilebilir. İnsanlar anadillerinin dışında ikinci bir dil olarak İngilizceyi tercih etmektedirler. İngilizce bugün teknoloji ve bilim dünyasının ortak dilidir ve hatta her geçen gün hemen her alanda giderek artan bir ortak iletişim dili olmaya da devam etmektedir (Smith, 2015). Bilim insanlarının yaptıkları çalışmaları herkesin anlayabileceği bir dilde yazmak istemeleri ve bunun için hemen hemen bütün ülkelerin kullandığı ortak iletişim dili olan İngilizceyi seçmeleri çok doğal bir davranıştır. Araştırma kapsamında incelenen makaleler toplamda 9 farklı dilde yazılmıştır. Türkçe yazılan makale sayısı 7'dir (\%2.4). Bu 9 dil içerisinde Türkçe 3. sıradadır. Hayat boyu öğrenme alanıyla ilgili olarak Türkiye'de artan ilginin diğer ülkelere oranla daha yüksek olduğu söylenebilir. Türkiye'de bu alanla ilgili tez çalışmaları 2007 yılı itibariyle başlamış olup, günümüzde daha da önem kazanarak ilerlemektedir. Ancak bu ilgi henüz istenen seviyede değildir (Yenen ve diğerleri, 2016). Bu alanda daha fazla çalışma yapılması ve alanyazına katkıda bulunulması gerekmektedir.

$\mathrm{Bu}$ araştırmanın amacı doğrultusunda incelenen makalelerde, nitel yöntemler diğer araştırma yöntemlerine göre daha çok tercih edilmiştir. Kullanılan araştırma yöntemleri incelendiğinde nitel yöntemler tüm araştırmaların yarısından daha fazlasında kullanılmıştır (\%62.3). Nitel araştırmalar olayların doğal ortamlarında gerçekçi ve bütüncül bir biçimde ortaya konmasına yönelik bir süreç izler, bir başka deyişle sosyal olguları bağlı bulundukları çevre içerisinde araştırmayı ve anlamayı ön plana alan araştırmalardır (Yıldırım \& Şimşek, 2016). Hayat boyu öğrenme aslında bir sonuçtan ziyade süreçtir. Gözlenmesi ve izlenmesi uzun zaman alan bir olgudur (Yenen ve diğerleri, 2016). Bu sebeplerden dolayı hayat boyu öğrenme alanıyla ilgili araştırmalarda nitel araştırma yöntemleri diğer yöntemlere göre daha fazla tercih edilmiş olabilir. Türkiye'de yayın yapan dergilerde yayınlanan makalelerin kullandıkları yöntemlere bakıldığındaysa nitel yöntemler ve nicel yöntemlerin aynı sayıda tercih edildiği sonucuna ulaşılmıştır. Aynı şekilde Yenen, Kılınç ve Bulut (2016) yılında yaptıkları çalışmada hayat boyu öğrenme ile ilgili yapılan tezleri incelemiş ve sonuç olarak hem nicel hem de nitel yöntemlerin eşit sayıda kullanıldığını bulmuşlardır. Ancak inceledikleri tezlerin içerisinde deneysel bir çalışmaya rastlamamışlardır.

Elde edilen bulgulara göre makalelerde kullanılan veri analiz yöntemleri içerisinde nitel veri analiz yöntemleri en çok tercih edilen veri analiz yöntemleridir. Hiçbir veri analiz yöntemi kullanılmayan 10 makale (\%3.37) bulunurken, sadece nitel veri analiz yöntemi kullanılan 135 makale $(\% 45.45)$ ve sadece nicel veri analiz yöntemi kullanılan 89 makale (\%29.97) bulunmaktadır. Her iki veri analiz yöntemini de kullanan makale sayısı 63'tür (\%21.21). Genel olarak nitel veri analiz yöntemleri 198 çalışmada (\%66.66), nicel veri analiz yöntemleri 152 çalışmada (\%51.17) kullanılmıştır. Bu sonuçlar makalelerde kullanılan yöntemleri de destekler şekilde bulunmuş olup, nitel veri analiz yöntemlerinin hayat boyu öğrenme gibi süreç odaklı konularda daha çok tercih edildiğini ortaya koymaktadır. Aynı zamanda hem nicel hem de nitel veri analiz yöntemlerinin birlikte kullanıldığı makale sayısının en az olması, bu konudaki eksikliğin bir göstergesi olarak yorumlanabilir. Araştırmalarda farklı veri analiz yöntemlerinin birarada kullanılması verilerin doğru analiz edilebilmesi ve daha güçlü sonuçlar elde edebilmek adına önemlidir (Göktaş, ve diğerleri, 2012). Hem nicel hem de nitel veri analiz yöntemlerinin birlikte kullanılması sonuçları daha güçlü kılacaktır (Çakmak, ve diğerleri, 2016; Gülbahar \& Alper, 2009). Bundan sonraki yapılacak olan çalışmalarda farklı veri analiz yöntemlerinin birlikte kullanılması bu eksikliğin giderilmesi adına tavsiye edilebilir.

Nitel veri analiz yöntemleri kendi içinde incelendiğinde elde edilen bulgulara göre betimsel veri analiz yöntemlerinin diğer nitel veri analiz yöntemlerine göre daha fazla tercih edildiği söylenebilir $(\mathrm{n}=102, \% 51.52)$. Bunun sebebi olarak nitel veri analiz yöntemleri içerisinde betimsel veri analizinin diğer yöntemlere göre daha kolay yapılabilmesi söylenebilir. Nicel veri analiz yöntemleri kendi içerisinde incelendiğindeyse sadece betimsel istatistik kullanılan makalelerin sadece kestirimsel istatistik kullanılan makalelere oranla daha çok tercih edildiği görülmektedir. Aynı şekilde burada da betimsel istatistiklerin kestirimsel istatistiklere göre daha kolay yapılabilmesi bir etken olabilir. Betimsel istatistiklerin içerisinde en fazla grafikle gösterim $(n=43, \% 36.39)$ ve 
frekans/yüzde ( $\mathrm{n}=32 \% 28.57)$ istatistikleri ön plana çıarken, kestirimsel istatistiklerde regresyon analizi ( $\mathrm{n}=28$, \%32.94) ön plana çıkmıştır.

Araştırma kapsamında incelenen makaleler veri toplama araçları bakımından incelendiğinde çalışmaların tamamına yakınının en az bir veri toplama aracı kullandığı görülmektedir ( $\mathrm{n}=269, \% 90.57)$. Bu veri toplama araçlarının içerisinde en çok dökümanlardan veri toplanmıştır ( $\mathrm{n}=101, \% 34.01)$. Bu sonuç makalelerde kullanılan yöntemleri ve kullanılan veri analiz yöntemlerini destekler niteliktedir. Kendi veri toplama aracını oluşturan ve kullanan makaleler de oldukça fazladır ( $\mathrm{n}=91, \% 30.64)$. Süreç değerlendirmelerinde araştırmacıların kendi veri toplama yöntemlerini oluşturması, sürece göre bu araçları geliştirmesi veya güncelleştirmesi oldukça yaygındır denebilir. Bu iki veri toplama aracını anketler takip etmektedir $(\mathrm{n}=68, \% 22.90)$. Bu sonuçlar Çakmak ve diğerleri, (2016) ve Gülbahar ve Alper (2009)'in çalışmalarında elde ettiği sonuçlarla ters düşmektedir. Söz konusu çalışmalarda anketin en çok kullanılan veri toplama aracı olduğu sonucuna ulaşılmıştır. Bu çalışmanın ulaştı̆̆ sonuçların farklı çıkmasının nedeni, farklı alanlardaki çalışmaların farklı veri toplama araçlarına ihityaç duyduğu şeklinde yorumlanabilir.

Makalelerin büyük çoğunluğunda katılımcılara rastlanmamaktadır. Katılımcıların belirtildiği makale sayısı 101'dir (\%34). Katılımcıların hemen hemen yarısı farklı meslek grupları veya farklı görevlerde bulunan bireylerdir $(\mathrm{n}=51, \% 50.5)$. Lisan öğrencileri, öğretim elemanları ve lisansüstü eğitime devam eden katılımcılar toplamda 61 (\%60.4) makalede katılımcı olarak yer almaktadır. Bu açıdan bakıldığında ise üniversitelerle ilişki içinde olan bireylerin hayat boyu öğrenme alanıyla ilgili çalışmalarda daha çok yer aldığı görülmektedir. Üniversite öncesi eğitime devam eden bireylerin de bu alandaki çalışmalara en az katıldığını söylemek mümkündür. Ortaöğretim, ortaokul ve ilkokula devam eden öğrenciler toplamda 6 makalede yer almaktadır (\%6). Hayat boyu öğrenmenin daha çok yetişkin eğitimi ile anılması bu sonuçların ortaya çıkmasında etken olabilir. Ancak hayat boyu öğrenme çok geniş kapsamlı bir alandır. Hayat boyu öğrenme becerilerinin erken yaşlarda bireylere kazandırılması önemlidir. Bu bağlamda üniversite öncesi eğitime devam eden bireyler üzerinde daha fazla araştırma yapılması da çok önemlidir.

Makalelerdeki katılımcıların yaşa göre dağılımları incelendiğinde katılımcıların yaşını belirten çok az sayıda çalışma olduğu görülmüş̧ür $(\mathrm{n}=49, \% 16.49)$. Bu çalışmalarda belirtilen katılımcı yaşları gruplandığında toplam 146 grup olduğu ve bu grupların içerisinde 30 yaş ve üzeri katılımcıların büyük çoğunluğu oluturduğu görülmektedir ( $\mathrm{n}=102, \% 69.86)$. Bunun sebebi olarak, hayat boyu öğrenme alanı, araştırmacılar tarafından daha çok yetişkinlere yönelik bir alan gibi yorumlandığı şeklinde düşünülebilir. Eğitim politikalarının başarısını ölçmek için de daha yaşlı bireyler bu çalışmaların katılımcıları olarak tercih edilmiş olabilir. Ancak hayat boyu öğrenme yalnızca yetişkinlere yönelik bir alan değildir. Hayat boyu öğrenme becerileri bireylere erken yaşlarda kazandırılması gereken bir beceri türüdür (Budak, 2009). Hayat boyu öğrenme alanıyla ilgili çalışmaların küçük yaş gruplarına daha fazla odaklanması gerekliliği ortadadır. Örgün eğitim içindeki aktif bireyler üzerinde bu alanda yapılacak olan çalışmalar ile hayat boyu öğrenme becerilerinin nasıl kazandırılacağı adına daha fazla veri elde edilebilir ve eğitim politikalarının geliştirilmesine katkıda bulunulabilir.

İncelenen makaleler içerisinde üzerinde çalışılan örneklem boyutları belirtilen makale sayısı 127'dir (\%49.76). $\mathrm{Bu}$ çalışmaların yarısından fazlası 101 kişi ve üzerinde katılımcıyla çalışmıştır ( $\mathrm{n}=78, \% 61.42)$. En çok 101-300 kişiyle çalış1 1 ış olup $(\mathrm{n}=30, \% 23.62)$, ikinci sırada 1000 ve üzeri sayıdaki katılımcıyla çalışıllmıştır $(\mathrm{n}=25$, \%16.69). Bu sonuçlara paralel olarak Bozkaya, Aydın ve Kumtepe (2012) yaptıkları çalışmada da 200'ün üzerinde katılımcıyla gerçekleşen çalışmaların çoğunluğa sahip olduğunu bulmuşlardır. Ancak Çakmak ve diğerleri, (2016) ve Göktaş ve diğerleri (2012) yaptıkları çalışmalarda ulaşıkları sonuçlar, araştırmalarda daha küçük örneklem büyüklüklerinin tercih edildiği yönündedir. Bu farklılık yine bahsi geçen araştırma alanları arasındaki farklılıktan kaynaklanıyor olabilir. Büyük örneklem gruplarıyla yapılan çalışmalardan elde edilen bulgular daha genel sonuçlara ulaşmamızı sağlar (Bozkaya, Aydın, \& Kumtepe, 2012). Eğitim politikası belirleme noktasında genele hitap eden sonuçlar daha kullanışlı olabileceğinden, hayat boyu öğrenme alanında yapılan çalışmalarda daha büyük örneklem grupları tercih edilmektedir denebilir.

Makalelerde kullanılan anahtar sözcüklere bakıldığında en çok "Lifelong Learning" anahtar sözcüğünün kullanıldığı görülmektedir. Ancak bu anahtar kelimenin dışında ön plana çıkan başka kelimeler yok denecek kadar azdır. Buna göre hayat boyu öğrenme alanı hemen her alanla ilişkilendirilebilecek bir çalışma alanıdır ş̧eklinde yorumlanabilir. Sonuç olarak, hayat boyu öğrenme alanında yapılan çalışmaları yayınlayan dergi çeşitliliğinin çok olduğu ancak bu dergilerin içinde Türkiye'de yayın yapan dergi sayısının az olduğu, makaleler yazılırken en çok İngilizce dilinin tercih edildiği, araştırma yöntemi olarak en çok nitel yöntemlerin kullanıldığı, betimsel veri analiz 
yöntemlerinin en çok tercih edilen olduğu, katılımcılar bakımından çok çeşitli örneklemler seçildiği, yaş grubu yüksek katılımcılarla daha çok çalışıldığı, örneklem boyutlarının genellikle büyük olduğu ve en çok "Lifelong Learning" anahtar sözcüğünün kullanıldığı bulunmuştur. Alanyazında hayat boyu öğrenme alanıyla ilgili makalelerdeki eğilimleri inceleyen çalışmaların sınırlı olduğu görlmektedir. Bu çalışmayla birlikte, hayat boyu öğrenme alanıyla ilgili makaleler belirli değişkenlere göre analiz edilmiş olup, söz konusu alanla ilgili olarak gelecek çalışmalara fikir vermesi açısından önerilerde bulunulmuştur.

Hayat boyu öğrenme alanı Türkiye'de yeni yeni ilgi görmeye başlayan bir alandır. Bu bakımdan daha fazla araştırma yapılması ve alanyazına katkıda bulunulması önerilebilir. Türkiye'de yayın yapan dergilerin hayat boyu eğitimle ilgili çalışmalara daha fazla yer vermesi, araştırmacıları söz konusu alanla ilgili daha fazla çalışma yapması için teşvik edebilir. Yapılacak olan çalışmalarda pek çok farklı örneklem türü üzerinden çalışılabileceği gibi özellikle üniversite öncesi eğitime devam eden bireylerle çalışılarak bu konudaki eksiklikler giderilebilir. Hayat boyu öğrenme alanıyla ilgili içerik analizi veya meta analiz çalışmalarına pek rastlanmamaktadır. Bu alanda daha fazla çalışma yapılması hayat boyu öğrenmenin anlaşılması ve gelecek araştırmalara yön göstermesi adına çok önemlidir. 


\section{References}

Aksoy, M. (2008). The impact of the principles of life long learning and career guidance on employability: A research study of hotels [Hayat boyu ögrenme ve kariyer rehberliği ilkelerinin istihdam edilebilirliğe etkileri: Otel işletmeleri üzerine bir uygulama]. Doctoral Dissertation, Gazi University, Ankara.

Alkan, C. (1987). Açıöğretim [Open education]. Ankara University Faculty of Educational Sciences, Publication number:157, Ankara.

Atik, A., \& Ata, A. (2018). Massive open online course (mooc) practices as alternative digital education platform [Alternatif dijital eğitim platformu olarak kitlesel çevrimiçi açık ders (kçad) uygulamaları]. Social Sciences, 13(4), 144-154.

Ayçiçek, B. (2016). An investigation on the lifelong learning competencies and life wide learning habits of lecturers in faculties of education [Ĕgitim fakültelerindeki ögretim elemanlarinin hayat boyu ögrrenme yeterlikleri ile hayat çapında ögrenme alışkanlıklarının incelenmesi]. Master Thesis, Mersin University, Mersin.

Bıkmaz, F. H., Aksoy, E., Tatar, Ö., \& Altınyüzük, C. A. (2013). The content analysis of phd theses completed in the field of curriculum and instruction (1974-2009) [Eğitim programları ve ögretim alanında yapılan doktora tezlerine ait içerik çözümlemesi (1974-2009)]. Education and Science, 38(168), 288-303.

Binay Eyüboğlu, F.A., \& Karaoğlan Yılmaz, F.G. (2018). Öğretmenlerin yaşam boyu öğrenme tutumları dijital yerli olma durumları ve teknoloji kabulü arasındaki ilişkinin birbirleri ile ve çeşitli değiş̧kenler açısından incelenmesi [Investigation of the relationships between lifelong learning attitudes, digital native status and technology acceptance of teachers in terms of each other and various variables]. International Journal of Education Science and Technology, 4(1), 1-17

Bozkaya, M., Aydın, İ. E., \& Kumtepe, E. G. (2012). Research trends and issues in educational technology: a content analysis of TOJET. Turkish Online Journal of Educational Technology-TOJET, 11(2), 264-277.

Budak, Y. (2009). Lifelong learning and human type that should be aimed at the primary school curriculums [Yaşamboyu öğrenme ve ilköğretim programlarının hedeflemesi gereken insan tipi]. Gazi University Journal of Gazi Educational Faculty (GUJGEF), 29(3), 693-708.

Büyüköztürk, Ş., Çakmak, E. K., Akgün, Ö. E., Karadeniz, Ş. \& Demirel, F. (2016). Scientific research methods (22th edition) [Bilimsel araştırma yöntemleri (22 bs.)]. Ankara: Pegem Publications.

Commission of The European Communities. (CEC) (2000). A memorandum on lifelong learning. (1832, SEC (2000)), Brussels. 03.04.2018 http://arhiv.acs.si/dokumenti/Memorandum_on_Lifelong_Learning.pdf

Çakmak, E. K., Özüdoğru, G., Bozkurt, Ş. B., Ülker, Ü., Ünsal, N. Ö., Boz, K., . Gül, H. Ü. (2016). Examination of educational technology articles within 2014 [2014 yılında eğitim teknolojileri alanındaki yayımlanan makalelerin incelenmesi]. Educational Technology Theory and Practice, 6(1), 80-108.

Demirel, M. \& Yağc1, E. (2012). Perceptions of primary school teacher candidates about lifelong learning [Sınıf öğretmeni adaylarının hayat boyu öğrenmeye ilişkin algıları]. Hacettepe University Journal of Education, 1, 100-111.

Dochy, F., Segers, M., Van den Bossche, P. \& Gijbels, D. (2003). Effects of problem-based learning: a metaanalysis. Learning and Instruction, 13(5), 533-568.

Ergüney, M. (2015). The future of distance education: MOOC (Massive Open Online Course) [Uzaktan eğitimin geleceği: MOOC (Kitlesel Açık Çevrimiçi Dersler)]. Journal of Research in Education and Teaching, 4(4), $15-22$.

Gelişli, Y. (2015). Practices of distance education for teacher training: history and development [Uzaktan eğitimde öğretmen yetiştirme uygulamalari: tarihçe ve gelişim]. Journal of Research in Education and Teaching, 4(3), 313-321.

Göktaş, Y., Küçük, S., Aydemir, M., Telli, E., Arpacık, Ö., Yıldırım, G., \& Reisoğlu, İ. (2012). Educational technology research trends in Turkey: a content analysis of the 2000-2009 decade [Türkiye'de eğitim 
teknolojileri araştırmalarındaki eğilimler: 2000-2009 dönemi makalelerinin içerik analizi]. Educational Sciences: Theory and Practice, 12(1), 177-199.

Gülbahar, Y., \& Alper, A. (2009). A content analysis of the studies in instructional technologies area [Öğretim teknolojileri alanında yapılan araştırmalar konusunda bir içerik analizi]. Ankara University Journal of Faculty of Educational Sciences, 42(2), 93-111.

Hanemann, U. (2015). Lifelong literacy: some trends and issues in conceptualising and operationalising literacy from a lifelong learning perspective. International Review of Education, 61(3), 295-326.

Kabataş, S., \& Karaoğlan Yılmaz, F. G. (2018). Evaluation of teachers' lifelong learning attitudes in terms of selfefficacy towards the standards of educational technology [Öğretmenlerin yaşam boyu ögrenme tutumlarının eğitim teknolojileri standartlarına yönelik öz-yeterlikleri açısından değerlendirilmesi]. Bartın Üniversitesi Ĕ̈itim Fakültesi Dergisi, 7(2), 588-608.

Karaoğlan Yılmaz, F. G., Dilen, A., \& Durmuş, H. (2018). The examination of high school students' selfefficacy levels of mobile learning tools [Lise öğrencilerinin mobil öğrenme araçlarını kullanma öz yeterlik düzeylerinin incelenmesi]. SDU International Journal of Educational Studies, 5(1), 1-12.

Ministry of Education (2006). Decisions of the seventeenth national education council [On yedinci milli eğitim şurası kararları]. Ankara: 28.04.2018 https://ttkb.meb.gov.tr/meb_iys_dosyalar/2017_09/29165619_17_sura.pdf

Ministry of Education. (2014). Turkey lifelong learning strategy document [Türkiye hayat boyu ögrenme strateji belgesi]. 12.03.2018 http://hbogm.meb.gov.tr/str/str.html

Oran, M., \& Karadeniz, Ş. (2007). Mobile learning role in internet based distance education [İnternet tabanli uzaktan eğitimde mobil öğrenmenin rolü]. IX. Academic Informatics Conference Presentations (p. 167-170). Kütahya: Dumlupınar University.

Özdamar Keskin, N. (2010). Mobile learning technologies and tools [Mobil öğrenme teknolojileri ve araçları]. XII. cademic Informatics Conference Presentations (p. 491-496). Muğla: Muğla University.

Sezer, B., Karaoğlan Yılmaz, F. G., \& Yılmaz, R. (2017). Comparison of online and traditional face-to-face inservice training practices: an experimental study [Çevrimiçi ve geleneksel yüz yüze hizmet içi eğitim uygulamalarının karşılaştırılması: deneysel bir çalışma]. Çukurova Üniversitesi Eğitim Fakültesi Dergisi, 46(1), 264-288.

Smith, L. E. (2015). English as an international language: No room for linguistic chauvinism. Journal of English as a Lingua Franca, 4(1), 165-171.

Taşçı, D., Aydın, C. H., Kumtepe, E. G., Kumtepe, A. T., Kııı, G. K., \& Dinçer, G. D. (2015). Analysis of lifelong adult education in Eskişehir [Eskişehir'de hayat boyu öğrenme başliği altinda yetişkin eğitiminin analizi]. Selçuk University the Journal of Institute of Social Sciences, 34, 197-211.

Topakkaya, A. (2013). Lifelong learning and possible contributions of Turkish Unıversities to this field [Hayat boyu öğrenme ve türk üniversitelerinin bu alana muhtemel katkıları]. International Journal of Social Science, 6(4), 1081-1092.

Wagner, D. A. (2015). Learning and literacy: A research agenda for post-2015. International Review of Education, 61(3), 327-341.

Yenen, E. T., Kılınç, H. H. \& Bulut, A. (2016). Investgation of postgraduate thesis related to lifelong learning [Hayat boyu öğrenme ile ilgili lisansüstü tezlerin incelenmesi]. Researcher Social Science Studies, 4(1), 8593.

Yıldırım, A. \& Şimşek, H. (2016). Qualitative research methods (10th edition) [Nitel araştırma yöntemleri (10 bs.)]. Ankara: Seçkin Publishing. 